\title{
2011 年東北地方太平洋沖地震における仙台市丘陵地造成宅地の被害分析 一盛土·切盛境界·切土における宅地被害率と木造建物被害率一
}

\author{
佐藤真吾 ${ }^{1)}$ 、風間基樹 ${ }^{2)}$ 、大野晋 ${ }^{3)}$ 、森友宏 ${ }^{4)}$ 、南陽介 ${ }^{5)}$ 、山口秀平 ${ }^{6)}$ \\ 1) 正会員 復建技術コンサルタント、室長 学士（工学） \\ e-mail : shingo-s@sendai.fgc.co.jp \\ 2) 正会員 東北大学大学院工学研究科、教授 博士（工学） \\ e-mail : kazama_motok@civil.tohoku.ac.jp \\ 3) 正会員 東北大学災害科学国際研究所、准教授 博士（工学） \\ e-mail : ohnos@archi.tohoku.ac.jp \\ 4) 正会員 東北大学大学院工学研究科、助教 博士 (工学) \\ e-mail : mori@ soill.civil.tohoku.ac.jp \\ 5) 復建技術コンサルタント、係長 修士（工学） \\ e-mail : minami@sendai.fgc.co.jp \\ 6) 正会員 復建技術コンサルタント、技師 修士（理工学） \\ e-mail : syuhei@sendai.fgc.co.jp
}

\begin{abstract}
要 約
本稿は、2011年東北地方太平洋沖地震における仙台市丘陵地造成宅地の被害について、盛 土・切盛境界・切土における宅地被害率と木造建物被害率について報告している。造成宅 地全体の被害、地震動特性（計測震度、地表最大加速度PGA、地表最大速度PGV）、地盤 特性（造成年代、現地盤勾配、旧地形勾配、盛土厚）、建物特性（建築年代）について、 それぞれ宅地被害率および木造建物被害率を分析した。その結果、宅地被害および木造建 物被害ともに、被害率が高い順に盛土・切盛境界・切土となった。また、切土に比べて盛 土と切盛境界の宅地被害率および木造建物被害率は2倍以上の值を示し、盛土および切盛 境界における地盤の影響が大きいことが明らかとなった。
\end{abstract}

キーワード： 地盤震害、造成宅地、谷埋め盛土、2011年東北地方太平洋沖地震

\section{1.はじめに}

丘陵地の造成宅地が地震被害を受けやすいことは過去の大地震の経験から周知の事実である ${ }^{1)}$ また、 丘陵地の造成宅地では、切盛境界と盛土で地震被害を受けやすいと言われている。しかしながら、仙台 市全域のような広域を対象として、宅地被害率および建物被害率を分析した事例は存在しない。この理 由は、これまで広域をカバーする切盛図が存在せず、その作成に多大な労力と時間を要するため、まと まった被害が発生した狭い範囲でしか分析できなかったことによる。2011年東北地方太平洋沖地震では、 仙台市内の丘陵地造成宅地で、宅地・建物・道路・ライフライン（地中埋設物）等の甚大な被害が発生 
したが、仙台市全域の切盛図（縮尺 $1 / 25,000 、 一$ 部、縮尺 $1 / 2,500$ 精度相当）2）を同地震前に作成済みであ ったことから、これらの被害が盛土および切盛境界に集中して発生していることが容易に判明した。そ の後、仙台市全域の切盛図 ${ }^{3)}$ を縮尺1/2,500 1/3,000精度相当で作成し、より正確に造成宅地の被害分析 ができるようになった。また、仙台市内において公の判定基準で調査した4,766箇所の宅地被害データと 46,608棟の木造建物被害データ、および45箇所の地震動観測点データ、宅地の造成年代等の情報が収集 できた。

本稿は、2011年東北地方太平洋沖地震で仙台市内の丘陵地造成宅地において発生した宅地被害および 木造建物被害について、盛土・切盛境界・切土の3区分における宅地被害率と木造建物被害率を各種被害 要因別に分析し、報告するものである。

\section{2. 使用データ}

\section{1 宅地被害}

宅地被害データは、仙台市内全域の丘陵地造成宅地を対象として被災宅地危険度判定 ${ }^{4}$ に基づいて判 定した結果のうち、「危険」または「要注意」に判定された全4,766宅地（仙台市調査、2011年12月現在） を被害宅地データとして用いた。ここに、被害宅地とは、同一宅地内にある擁壁・宅地地盤・のり面の 3つの宅地構成要素のうち、危険度判定で4.5点以上となったものが1つ以上確認された宅地を示す。

\section{2 木造建物被害}

木造建物被害データは、仙台市内全域の丘陵地造成宅地における罹災判定棟数の全 46,608 箇所（仙台 市調査、2011年12月現在）を用いた。ここに、罹災判定は、国が示した平成23年東北地方太平洋沖地震 に係る住家被害認定の調査方法（平成23年4月改正）5）に基づいて仙台市によって行われたものである。 なお、1宅地1建物であるが、宅地被害と木造建物被害は同時に発生していない。

\section{3 盛土・切盛境界・切土区分}

丘陵地造成宅地の盛土・切盛境界・切土の区分は、図1に示寸切盛図を使用した。ここに、使用した切 盛図は、造成前後の地形データを生成し、両者の差分をとることにより切土および盛土厚さを算出して 作成したものである。切盛図の作成範囲は、仙台市内全域において、造成前後の地形図や空中写真、現 地の状況等を参考に、切盛の発生した箇所を抽出して決定している。

造成前の地形データは、旧版地形図（縮尺 $1 / 3,000$ 、精度 $\pm 0.8 \mathrm{~m} \sim 1.4 \mathrm{~m}$ ）または米軍撮影空中写真（撮影 縮尺1/16,000、精度 $\pm 0.6 \mathrm{~m} \sim 1.6 \mathrm{~m} ）$ から生成したものである。また、造成後の地形データは、基盤地図情 報（国土地理院）の数值標高モデル（5 mメッシュ）または開発許可時の地形図（ただし、2008年以降の 場合）から生成したものである。このため、切盛図の精度( ${ }^{6}$ は、使用した地形データの精度から $\pm 0.6 \mathrm{~m} \sim$ $1.6 \mathrm{~m}$ となり、概ね $\pm 2.0 \mathrm{~m}$ と判断される。

切盛境界については、切盛図の精度が概ね $\pm 2.0 \mathrm{~m}$ であることから、切盛厚さが $\pm 2.0 \mathrm{~m}$ の範囲内にある ものを切盛境界と定義し、その部分の被害を切盛境界の被害としている。

\section{4 造成年代}

造成年代は、「仙台市宅地造成履歴等情報マップ ; 造成年代図」（仙台市、2013年3月作成）7）に基づ いている（図2参照）。また、今回用いた造成年は造成開始年とした。

\section{5 現地盤勾配}

現地盤勾配は、国土地理院基盤地図情報（5mメッシュ標高ポイントデータ）を用いてGISにより抽出 した。地盤勾配データの作成は、ArcGISを用いて、対象メッシュとその近隣メッシュとを比較し、それ らの值の最大変化率を計算で求めた ${ }^{8)}$ 。一般に、造成地の現地盤勾配は最大 10 度程度以下であるが、同 勾配が10度以上を示寸箇所は、周囲に急こう配ののり面等が存在することを意味する。 


\section{6 旧地形勾配}

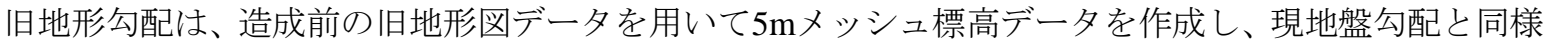
の方法でGISにより求めた。

\section{7 地震動特性}

地震動特性（計測震度、地表面最大加速度（以下、PGAと呼ぶ）、地表面最大速度（以下、PGVと呼 ぶ））は、仙台市内の地震観測データ9）（図6参照）を地下構造モデルによる非線形地盤増幅を補正し空 間補間したものを用いた（図7～9参照）。推定方法は以下に示すとおりである。なお、地震動特性とし ては、SI值、修正計測震度、各種スペクトル強度など、被害との相関分析に用いられる地震動指標値が 数多く存在するが、今回は計測震度、PGA、PGVの3つの指標を対象とした。ただし、本論文では過去の 地震記録で相関の高い周期带の応答スペクトルから計測震度、PGA、PGVに換算している11)ため、それ ぞれ周期 $0.4 〜 1.0(\mathrm{~s}) 、 0.1 \sim 0.3(\mathrm{~s}) 、 0.8 \sim 4.0(\mathrm{~s})$ のスペクトル振幅值を表しているものと見なして良い。

(1) 推定方法の概要

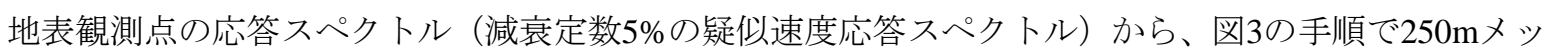
シュの応答スペクトル分布を求め、それを計測震度、PGA、PGV、に換算して最大值指標の分布を求め た。このうち、応答スペクトル分布の推定手法は大野・柴山 ${ }^{10)}$ 、応答スペクトルから最大值指標への換

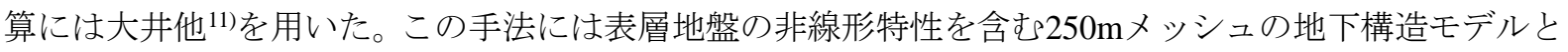
補間のための空間相関モデルが必要であり、それぞれ下記のものを用いた。

（2）地下構造モデル

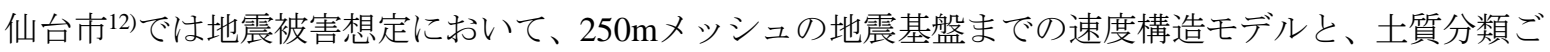
との表層地盤の非線形特性（剛性・滅衰の歪依存性）モデルを用いている。ここではそのモデルをその まま用いた（図4参照）。

(3) 空間相関モデル

応答スペクトルの周期ごとに観測バリオグラム（距離による相関の程度）を求め、図5のように、球形 モデルでフィッティングして理論バリオグラムを定め、クリギングで周期ごとに応答スペクトルの空間 補間を行った。

（4）実測値と推定值の関係

実測值における計測震度、PGA、PGVの各関係を図10に、上記方法による推定值における同関係を図 11にそれぞれ示す。これより、造成宅地内の地震動特性は、実測值では計測震度5.41〜 6.41、PGA320〜 $850 \mathrm{Gal} 、 \mathrm{PGV} 30 \sim 109 \mathrm{~cm} / \mathrm{s}$ がそれぞれ得られたが、同推定值では計測震度5.44〜5.98、PGA372〜 660Gal、 PGV37〜 $56 \mathrm{~cm} / \mathrm{s}$ となった。また、実測值と推定値における計測震度、PGA、PGVの関係を、盛土・切盛 境界・切土の観測点ごとに分類して図12に示寸。同図より、計測震度の推定值は実測值よりも全体に最 大 0.2 程度小さな值を示す (ただし、実測值が6.41地点の盛土上のデータは推定值の方が 0.4 程度小さい)。

PGAについては、切盛境界と切土上のデータの推定值は実測值と比べて概ね $\pm 100 \mathrm{Gal}$ 以内を示すが、盛 土上のデータは概衫 $\pm 200 \mathrm{Gal}$ 示す。PGVについては、切土上のデータの推定值は実測值と比べて概ね $5 \mathrm{~cm} / \mathrm{s}$ 程度大きい值を示すが、盛土上では推定值の方が最大 $60 \mathrm{~cm} / \mathrm{s}$ 程度小さな值、切盛境界では推定值の 方が最大 $20 \mathrm{~cm} / \mathrm{s}$ 程度小さな值を示寸。さらに、盛土上で地震動が大きく増幅するような場所では、計測 震度とPGA、PGVの推定值はそれぞれ約6.0、約700Gal、約60 $\mathrm{cm} / \mathrm{s}$ で頭打ちになっていることにも留意す る必要がある。

同一地点にもかかわらず実測值と推定值が異なる主な理由は、前述の通り過去の地震記録で相関の高 い周期帯の応答スペクトルを介して推定值を求めているが、実測值ではそれ以外の周期帯の寄与が大き いことがあるためである。上記のような理由で指標を厳密に再現できないものの、本論文で用いている 手法は、地盤構造の影響を地下構造モデルの等価線形応答解析の形で解析的に評価できる利点が大きい ため、上記推定值を用いた。 


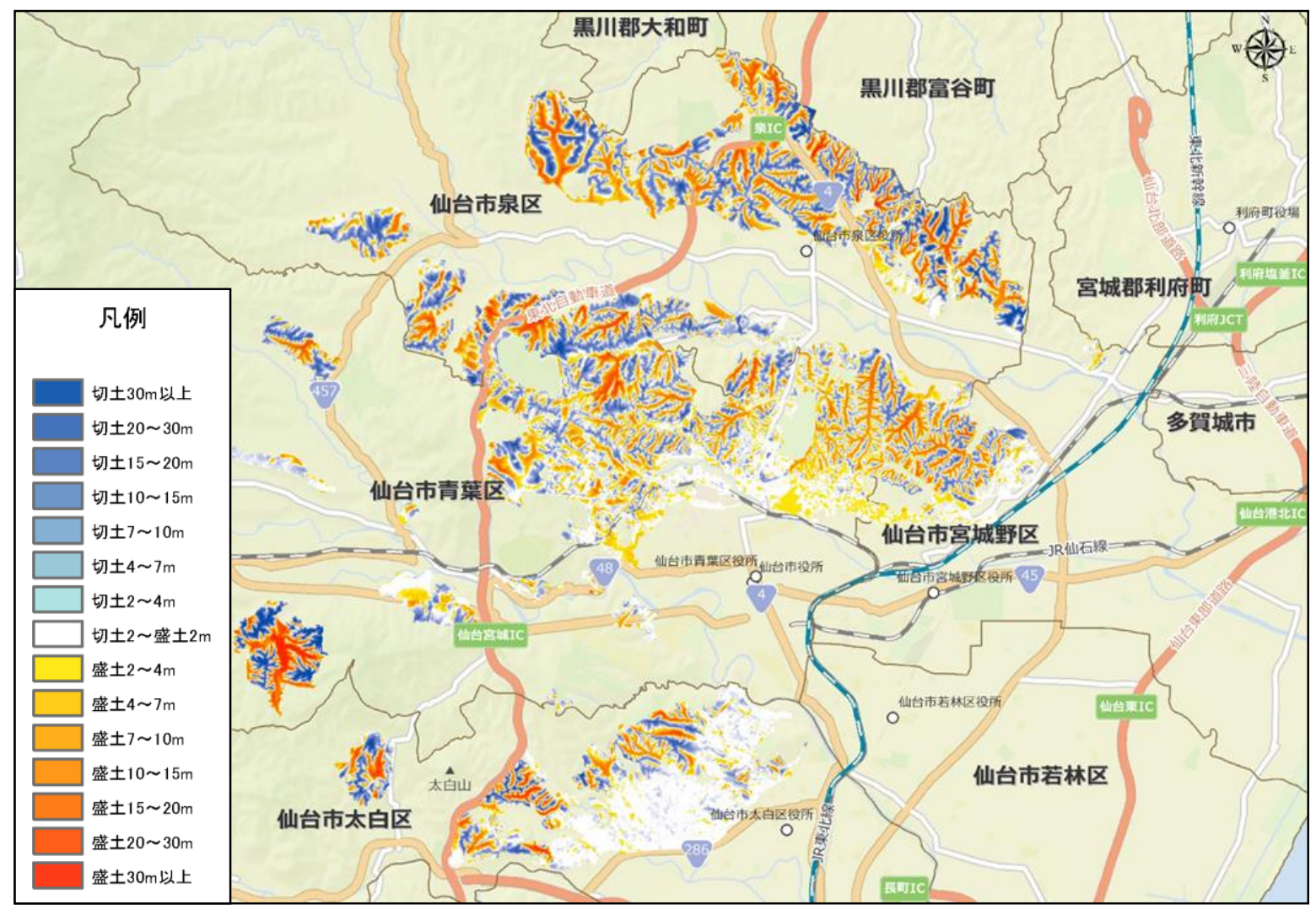

図1 仙台市造成宅地の切盛図 ${ }^{3)}$

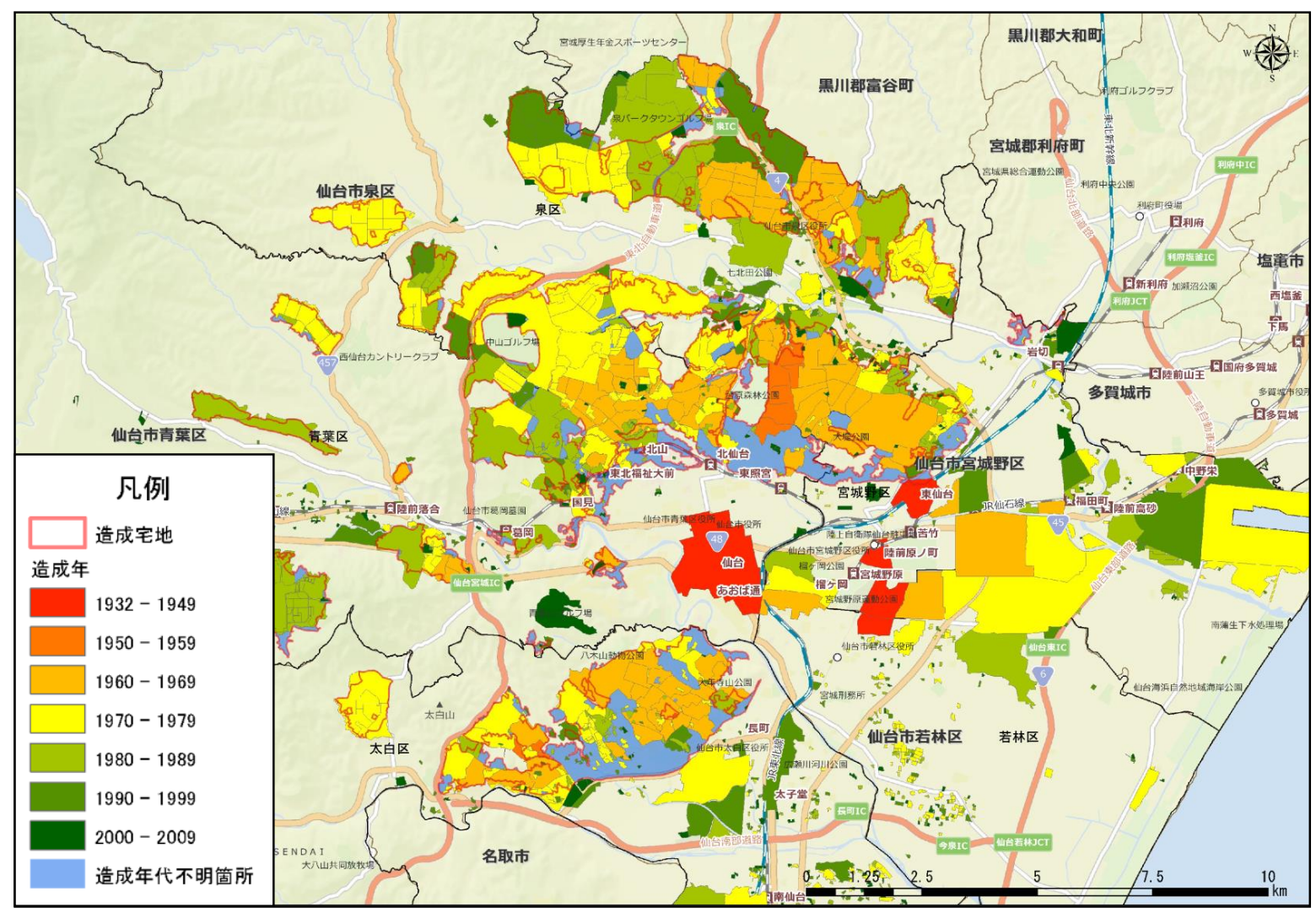

図2 仙台市造成年代図 ${ }^{7}$ 


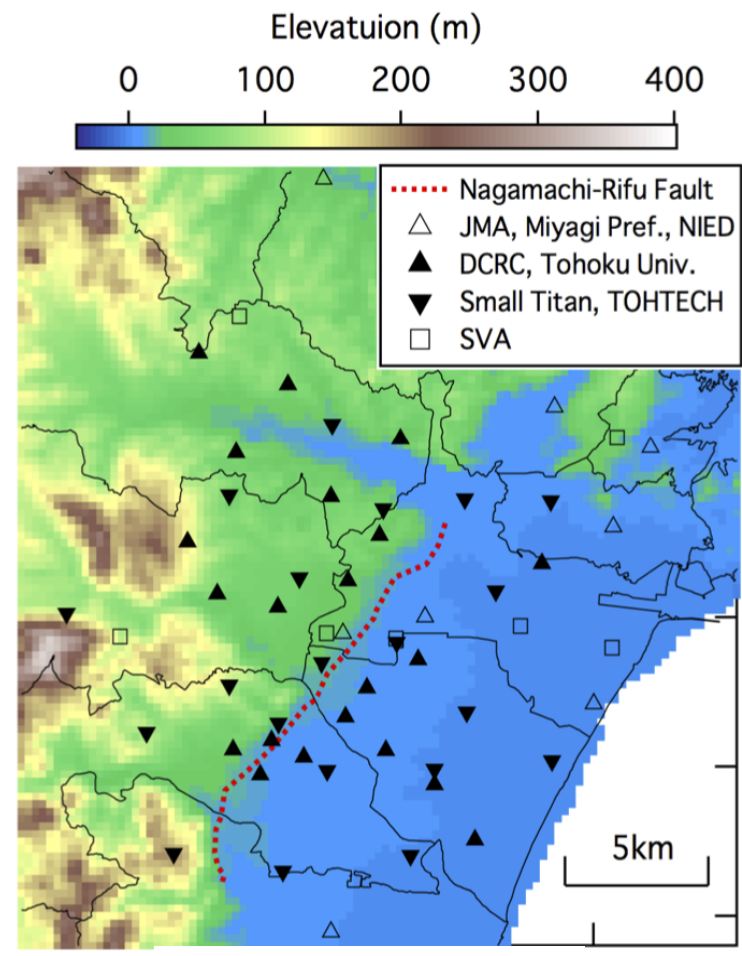

地震動観測地点位置図

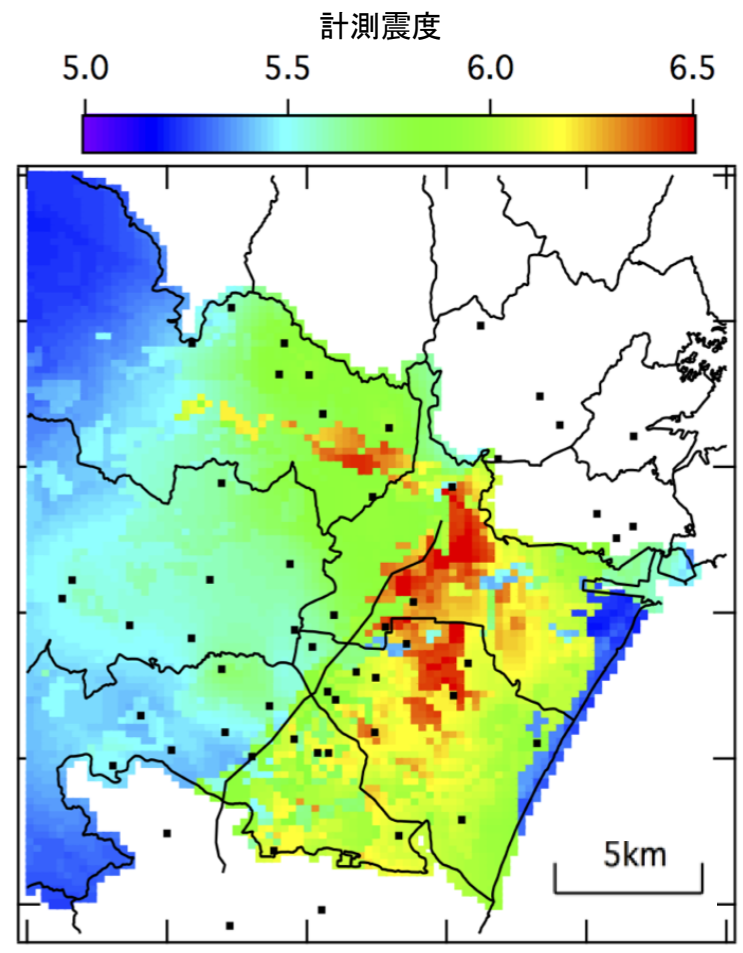

計測震度推定図

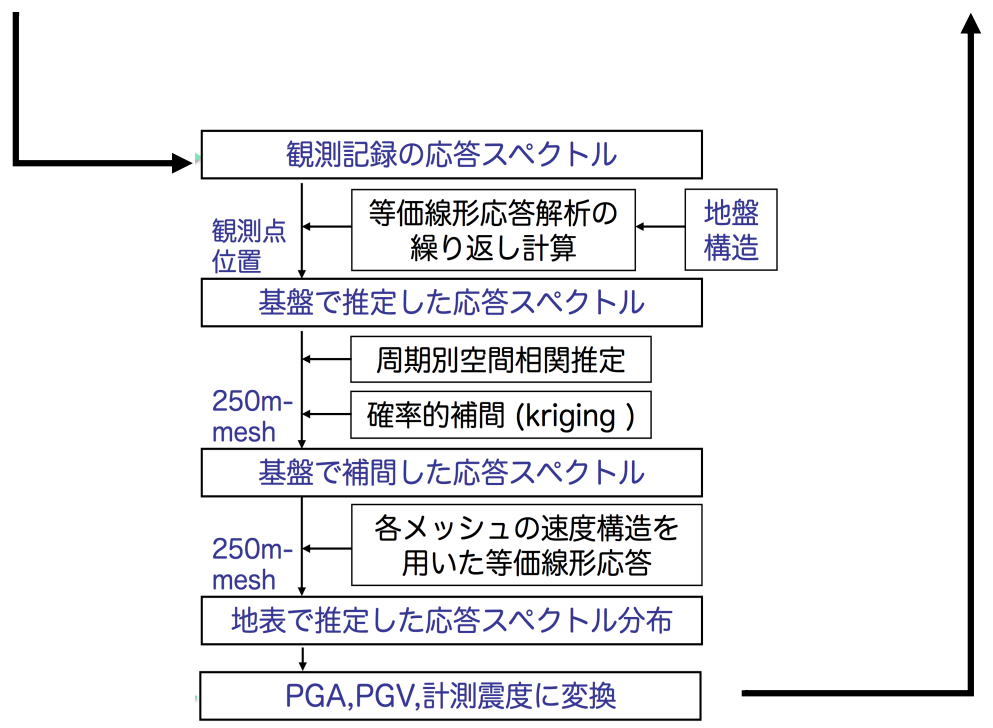

図 3 推定フロー 


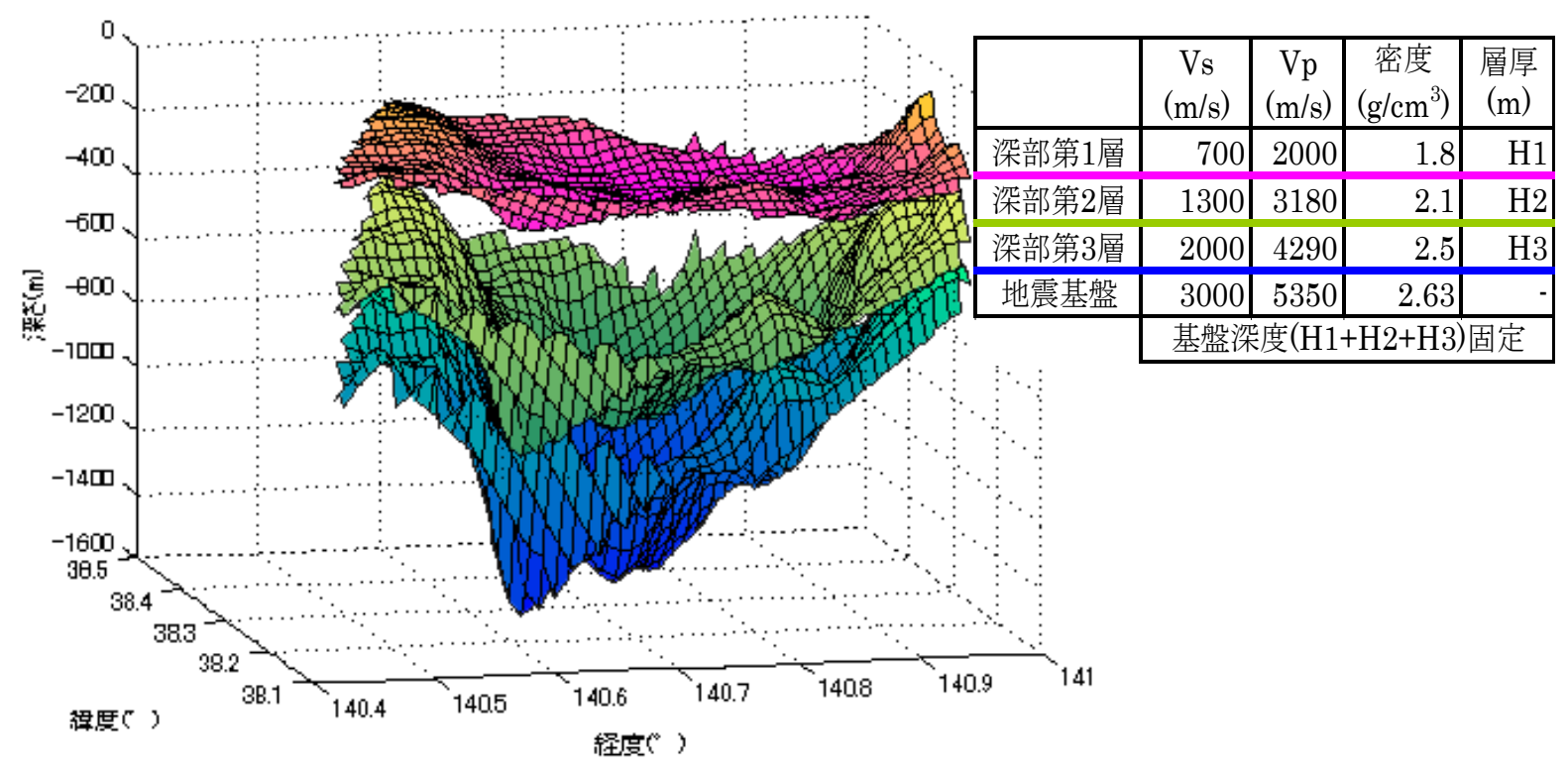

（a）三次元深部構造

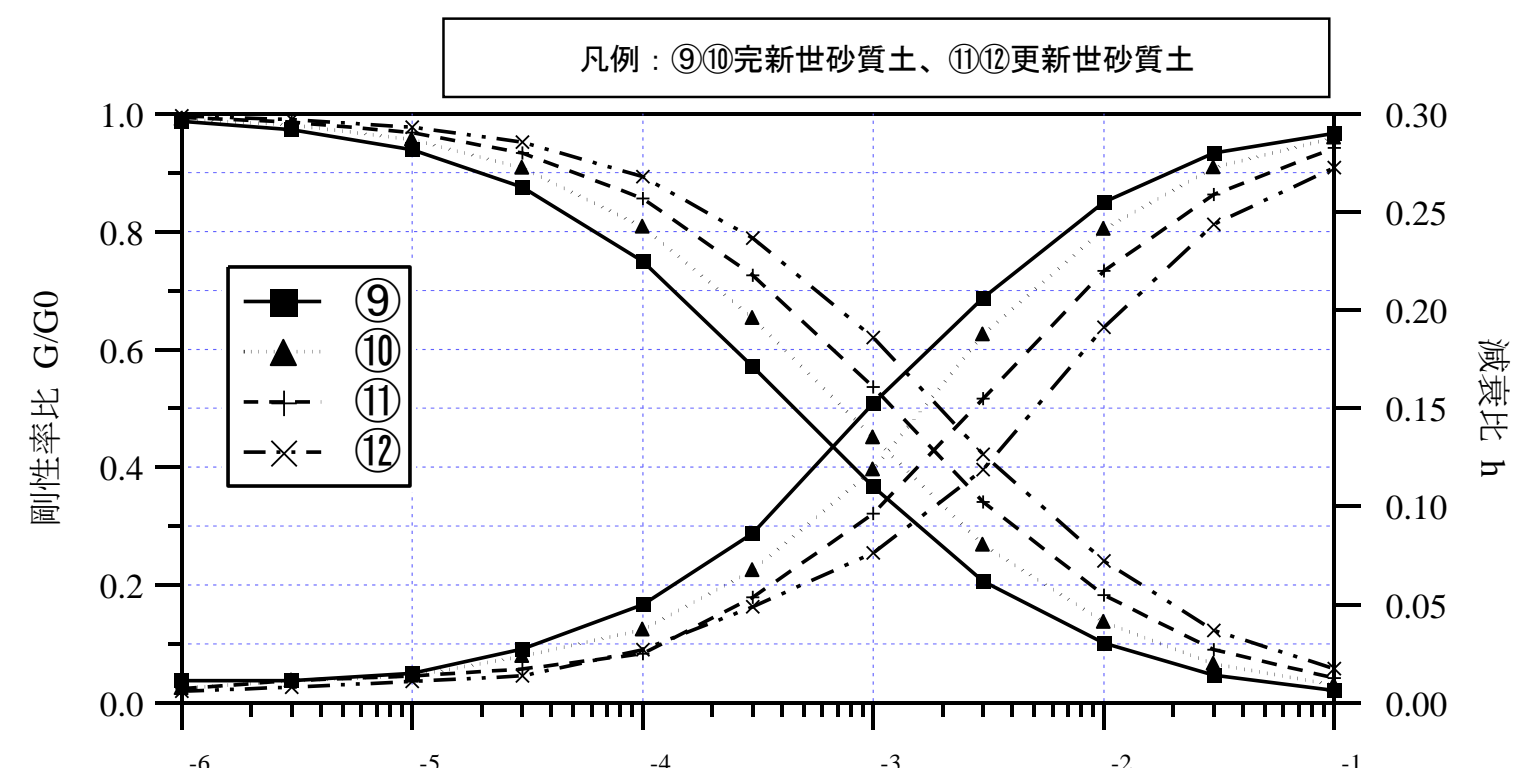

（b）表層地盤の非線形

$10^{-4} \quad 10^{-3}$

せん断歪振幅 $\gamma$

特性の例

図4 三次元深部構造と表層地盤の非線形特性の例12) 


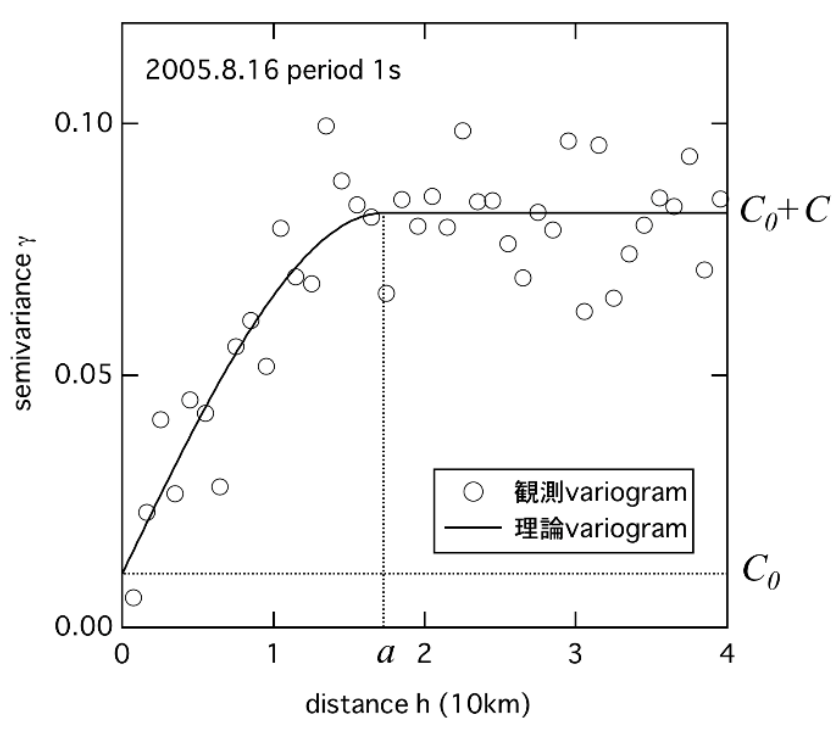

図5空間相関モデルの例 ${ }^{10}$

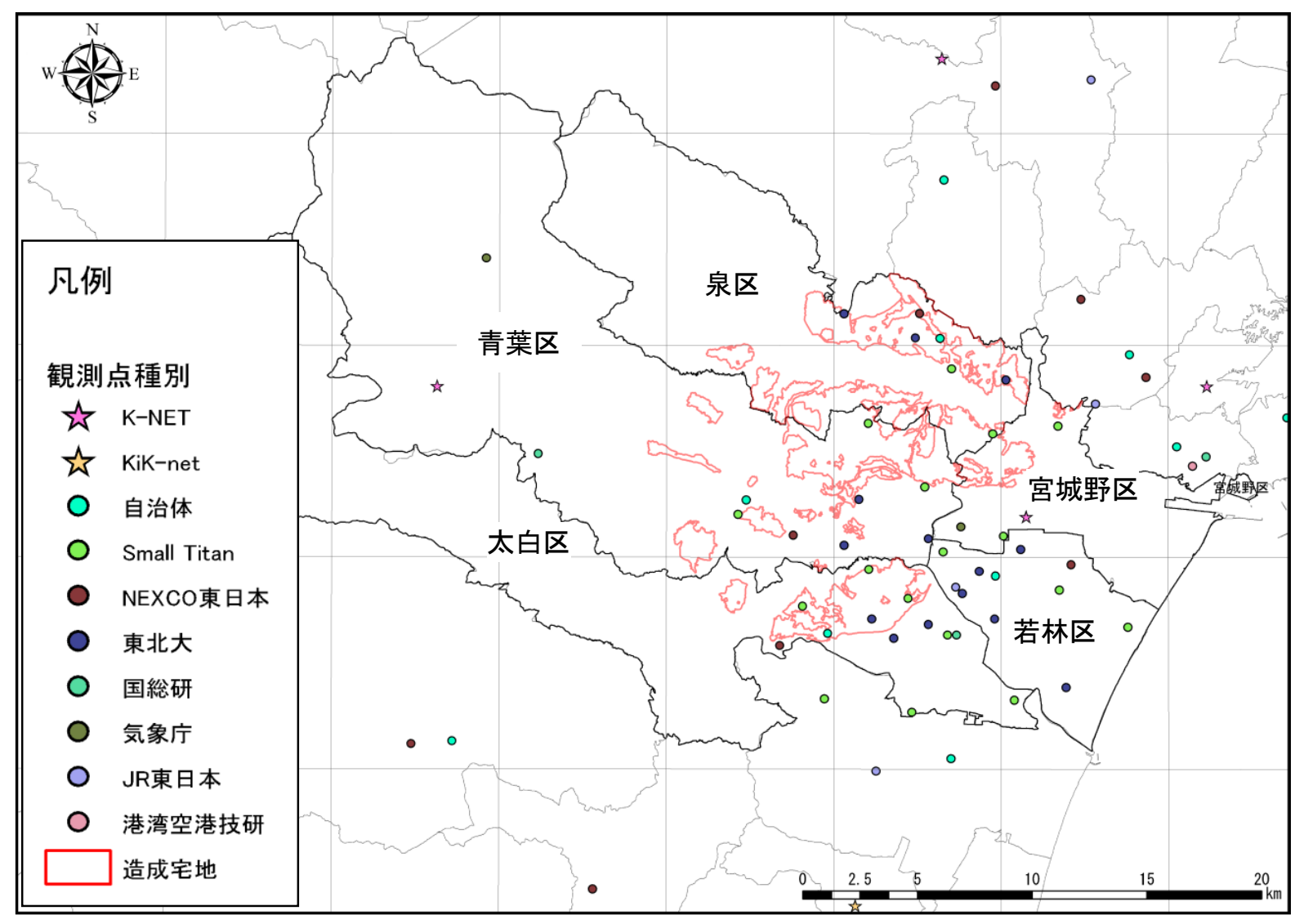

図6 地震動の観測点分布図 


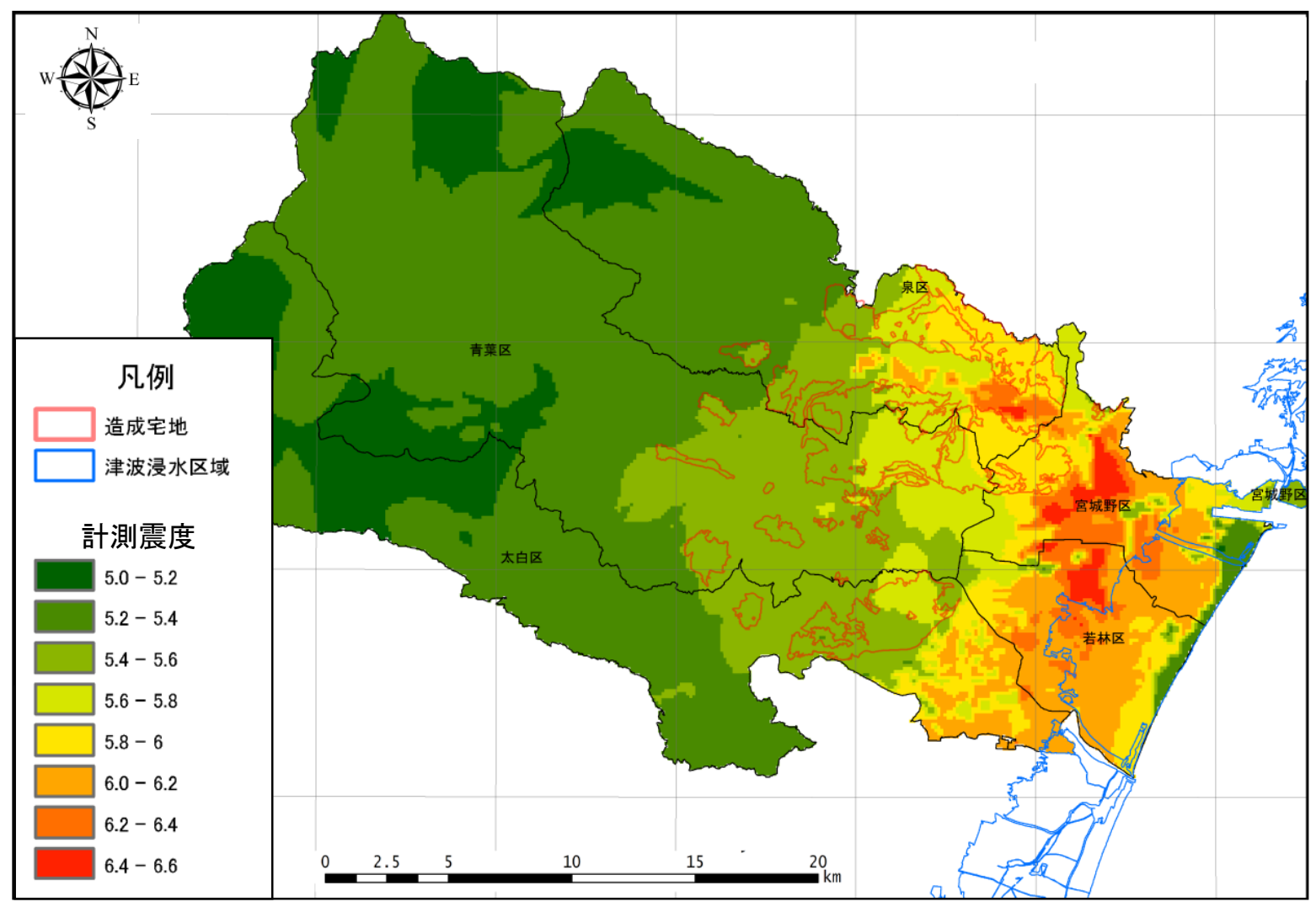

図7計測震度分布図

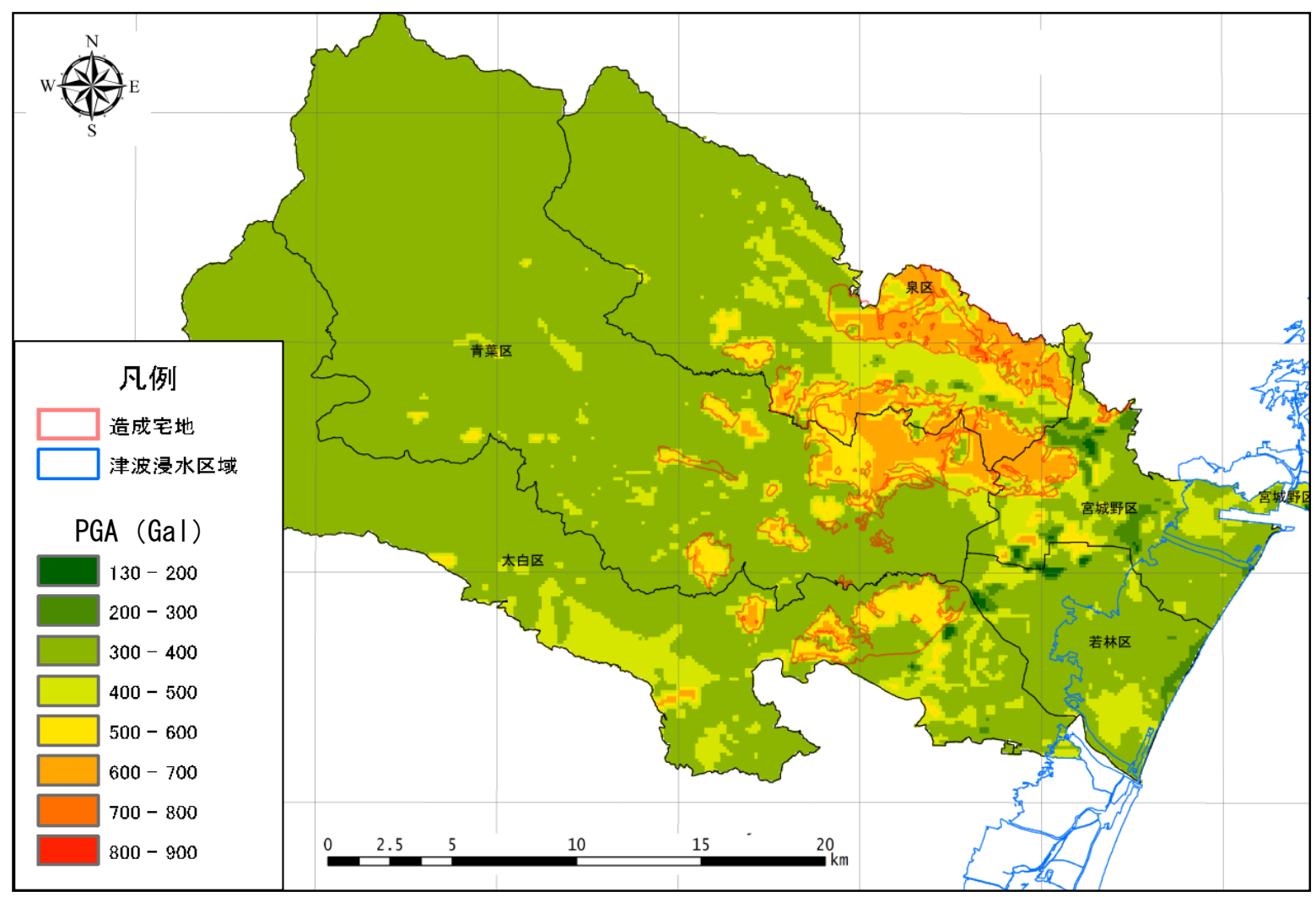

図8 PGA分布図 


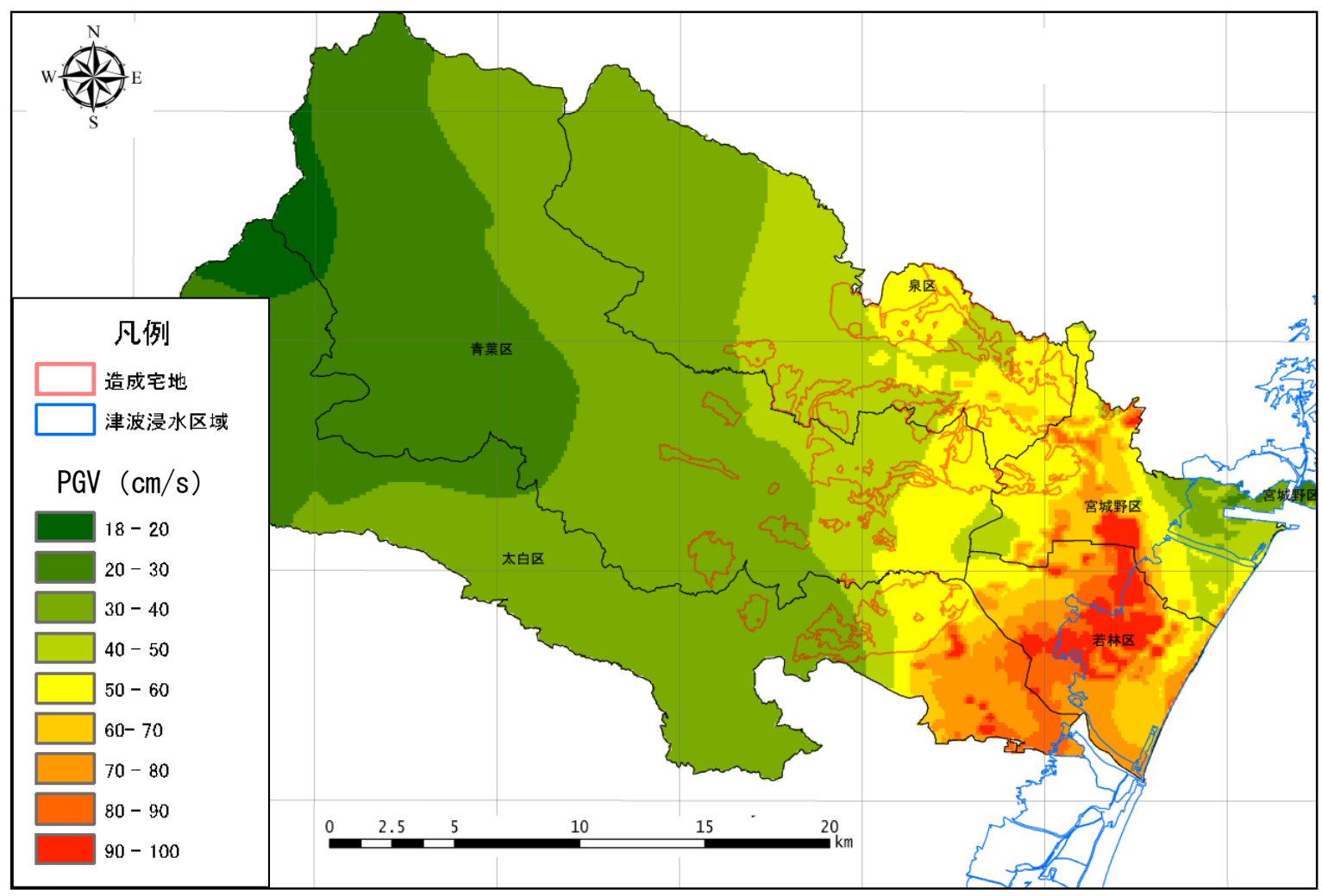

図9 $\quad$ PGV分布図

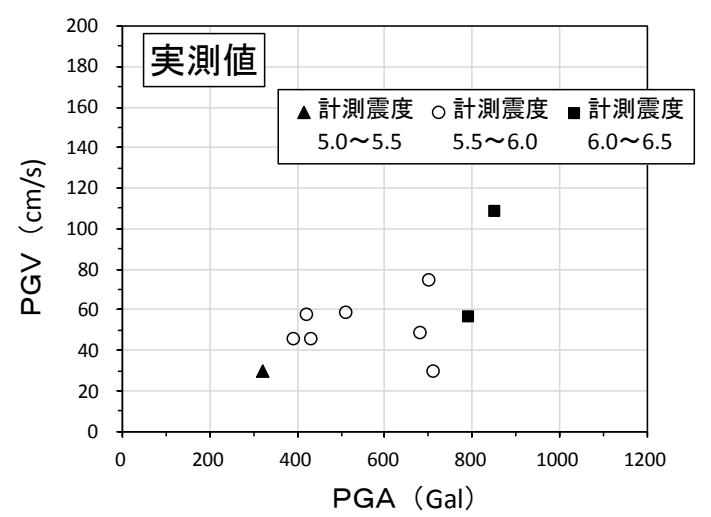

図10 計測震度・PGA ・PGVの関係（実測値）

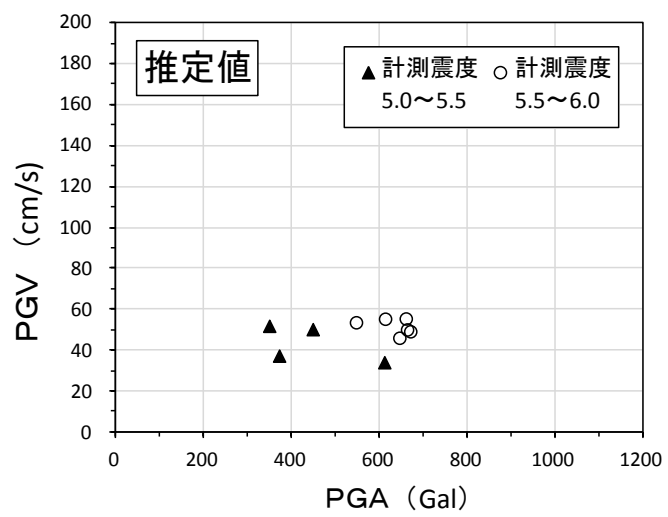

図11 計測震度·PGA - PGVの関係（推定值）

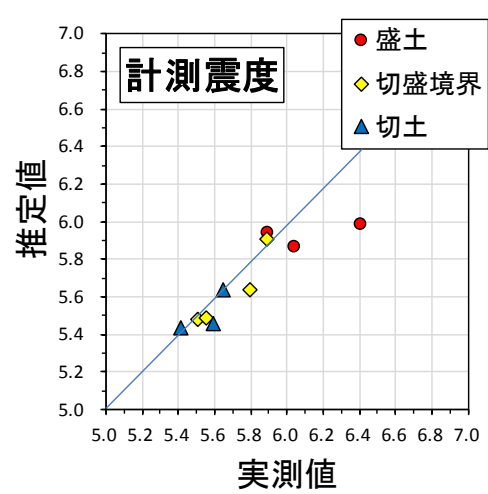

(a) 計測震度

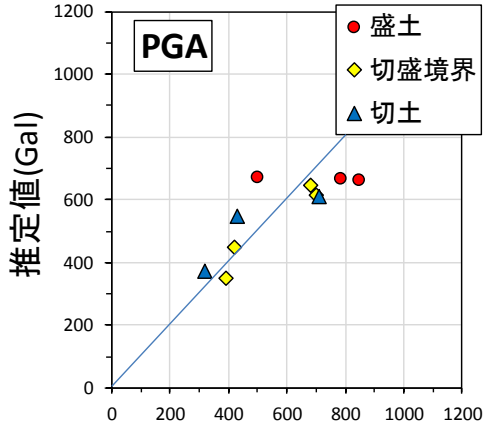

実測値(Gal)

(b) PGA

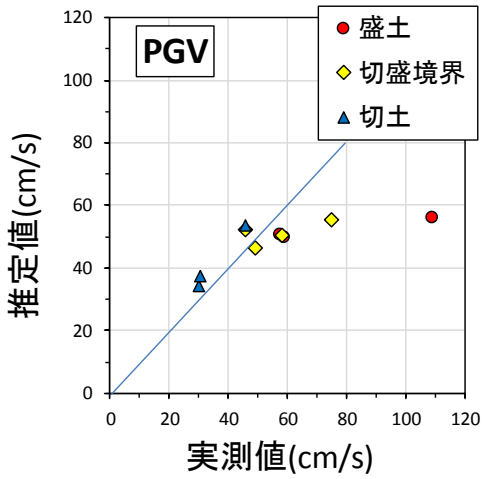

(c) PGV

図12 実測值と推定値の関係 


\section{3. 盛土・切盛境界・切土区分における被害分析}

\section{1 宅地被害および木造建物被害の割合}

宅地被害および木造建物被害について、被害数のみに着目して造成宅地で発生した全被害を母数とし た場合の盛土・切盛境界・切土でそれぞれ占める割合をまとめて表1および図13に示す。同図表より、危 険宅地あるいは要注意宅地と判定された宅地被害箇所が占める割合は、盛土 $55.1 \%$ 、切盛境界 $31.6 \%$ 、切 土13.3\%が得られた。これは、切土の被害割合を基準にすると、盛土は4.1倍、切盛境界は2.4倍高い被害 割合である。

また、木造建物被害のうち全壊、大規模半壊、半壊と判定された被害の合計（以下、半壊以上という） が占める割合は、盛土 $47.2 \%$ 、切盛境界 $30.7 \%$ 、切土 $22.1 \%$ 年られた。同榚に切土の被害割合を基準に すると、盛土は2.1倍、切盛境界は1.4倍高い被害割合である。

表1＼cjkstart切土・盛土・切盛境界区分と宅地被害および木造建物被害の関係

\begin{tabular}{|c|c|c|c|c|c|c|c|c|}
\hline & \multicolumn{4}{|c|}{ 被害件数（件） } & \multicolumn{4}{|c|}{ 被害割合（\%） } \\
\hline & 盛土 & 切盛境界 & 切土 & 計 & 盛土 & 切盛境界 & 切土 & 計 \\
\hline 宅地被害 & 2,626 & 1,505 & 635 & 4,766 & $55.1 \%$ & $31.6 \%$ & $13.3 \%$ & $100 \%$ \\
\hline 木造建物被害(半壊以上) & 9,069 & 5,890 & 4,247 & 19,206 & $47.2 \%$ & $30.7 \%$ & $22.1 \%$ & $100 \%$ \\
\hline
\end{tabular}

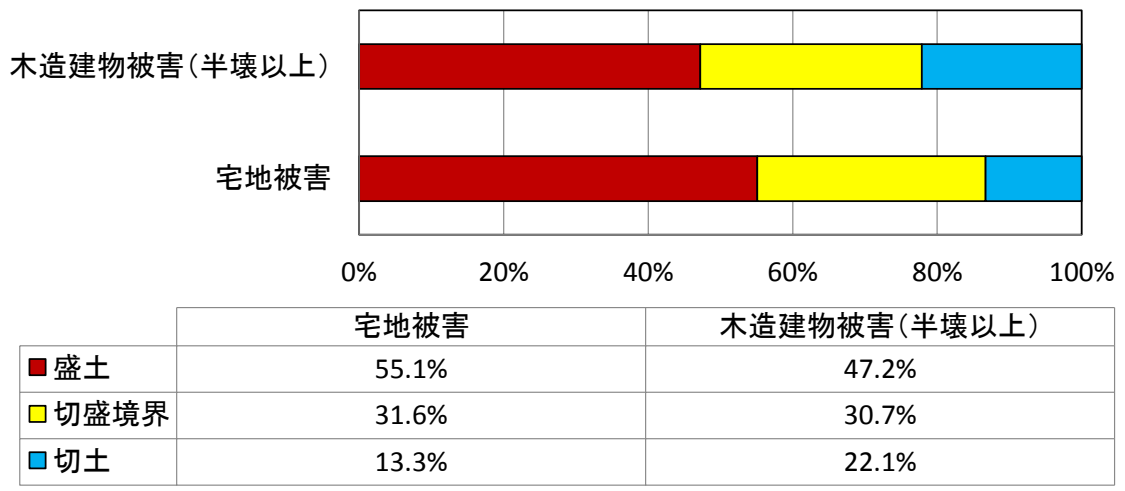

図 13 切土・盛土・切盛境界区分と宅地被害および木造建物被害の関係

\section{2 宅地被害率および木造建物被害率}

盛土・切盛境界・切土上の被害の区分と宅地被害率の関係を、表2および図14に示す。ここに、被害率

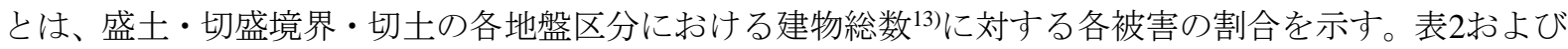
図14より、宅地被害率は、盛土4.8\%、切盛境界3.2\%、切土1.1\%を示す。これは、切土の被害率を基準と すると、盛土は4.4倍、切盛境界は2.9倍高い被害率である。

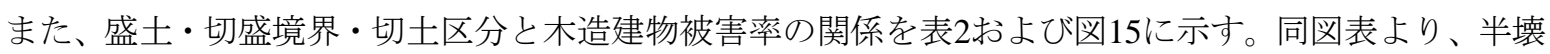
以上の木造建物被害率は、盛土 $16.6 \%$ 、切盛境界 $12.6 \%$ 、切土 $7.3 \%$ であるこがわかる。これは、切土の 被害率を基準とすると、盛土は2.3倍、切盛境界は1.7倍高い被害率である。同様に、全壊被害率では切土 と比較して、盛土は6.3倍、切盛境界は4.3倍高い被害率を示す。一方、一部損壊被害率では、盛土・切土・ 切盛境界ともに差がなく、概ね $217 \%$ 程度の被害率が得られた。 
表2＼cjkstart切土・盛土・切盛境界区分と宅地被害率および木造建物被害率の関係

\begin{tabular}{|c|c|c|c|c|c|c|c|c|}
\hline & & \multicolumn{4}{|c|}{ 被害件数（件） } & \multicolumn{3}{|c|}{ 被害率（\%) } \\
\hline & & 盛土 & 切盛境界 & 切土 & 計 & 盛土 & 切盛境界 & 切土 \\
\hline \multirow{3}{*}{ 宅地被害 } & 宅地被害 & 2,626 & 1,505 & 635 & 4,766 & $4.8 \%$ & $3.2 \%$ & $1.1 \%$ \\
\hline & 無被害 & 51,711 & 45,294 & 57,936 & 154,941 & $95.2 \%$ & $96.8 \%$ & $98.9 \%$ \\
\hline & 計 & 54,337 & 46,799 & 58,571 & 159,707 & $100.0 \%$ & $100.0 \%$ & $100.0 \%$ \\
\hline \multirow{6}{*}{$\begin{array}{c}\text { 木造建物 } \\
\text { 被害 }\end{array}$} & 全壊 & 1,049 & 591 & 151 & 1,791 & $1.9 \%$ & $1.3 \%$ & $0.3 \%$ \\
\hline & 大規模半壊 & 1,487 & 910 & 390 & 2,787 & $2.7 \%$ & $1.9 \%$ & $0.7 \%$ \\
\hline & 半壊 & 6,533 & 4,389 & 3,706 & 14,628 & $12.0 \%$ & $9.4 \%$ & $6.3 \%$ \\
\hline & 一部損壊 & 9,673 & 7,732 & 9,997 & 27,402 & $17.8 \%$ & $16.5 \%$ & $17.1 \%$ \\
\hline & 無被害 & 35,595 & 33,177 & 44,327 & 113,099 & $65.5 \%$ & $70.9 \%$ & $75.7 \%$ \\
\hline & 計 & 54,337 & 46,799 & 58,571 & 159,707 & $100.0 \%$ & $100.0 \%$ & $100.0 \%$ \\
\hline
\end{tabular}
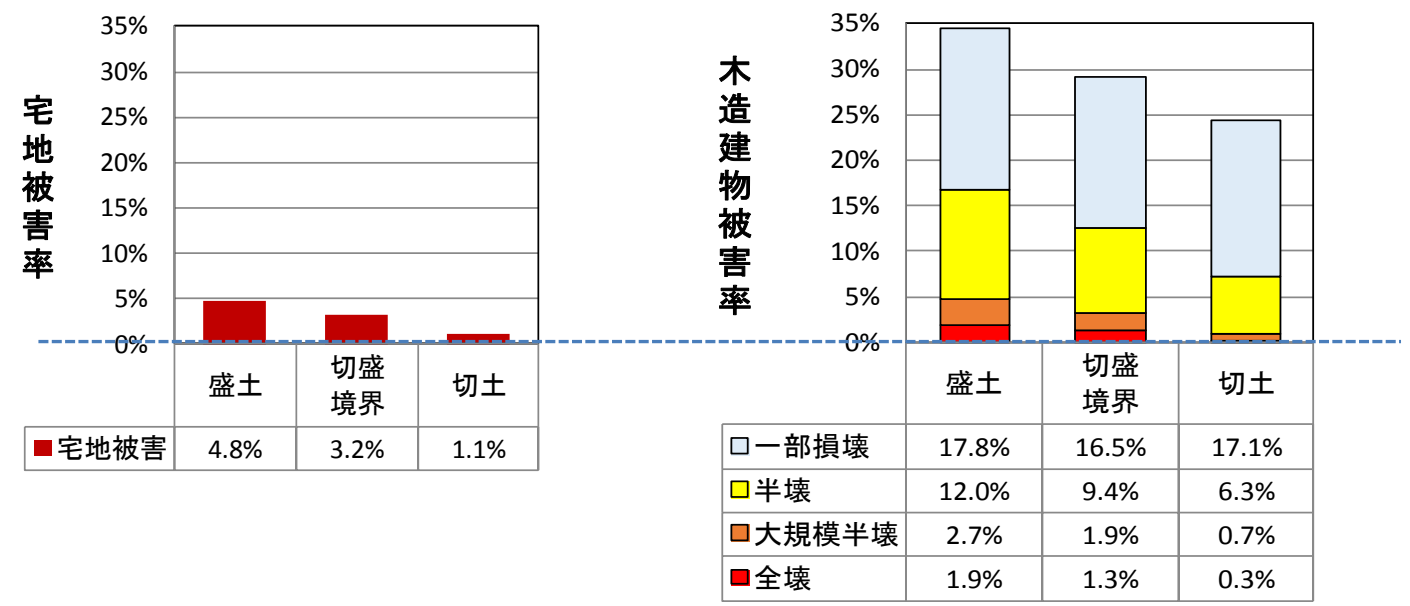

図 14 切土・盛土・切盛境界区分と 宅地被害率の関係

図 15 切土・盛土・切盛境界区分と 木造建物被害率の関係

\section{3 地震動特性別被害}

\section{3.1 計測震度と被害率の関係}

(1) 計測震度と宅地被害率の関係

盛土・切盛境界・切土区分における計測震度と宅地被害率の関係を図16に示す。ここに、今回得られ た宅地被害データは、計測震度が5.2〜 6.0 の範囲である。計測震度の階級区分は、各階級のデータ数が全 対象データ数の $10 \%$ 以上となる範囲を任意に設定し、全データの $1 \%$ 程度以下の階級は除外した。図16よ り、計測震度（5.8 6.0）で比較すると、宅地被害率は盛土 $4.3 \%$ 、切盛境界 $4.1 \%$ 、切土 $1.2 \%$ を示し、切 土の被害率を基準にすると盛土は3.6倍、切盛境界は3.4倍高い被害率である。また、宅地被害率は、切盛 境界と切土では計測震度に比例して増加する傾向が認められるが、盛土では計測震度の増加との比例関 係は認められない。

（2）計測震度と木造建物被害率の関係

盛土・切盛境界・切土区分における計測震度と木造建物被害率の関係を図17に示す。また、図18には 全壊被害と半損以上の被害について、近似曲線とともに示す。ここに、今回得られた建物被害データは、 計測震度が5.2〜6.0（切盛境界は6.2）の範囲である。計測震度の階級区分は、各階級のデータ数が全対象 データ数の $10 \%$ 以上となる範囲を任意に設定し、全データの $1 \%$ 程度以下の階級は除外した。図17より、 
全壊、大規模半壊、半壊の木造建物被害率は、盛土、切盛境界、切土ともに、計測震度に比例して増加 しているが、一部損被害率ではその傾向が認められない。また、図18より、計測震度（5.8～6.0）で比較 すると、全壞被害率は盛土 $2.5 \%$ 、切盛境界 $2.0 \%$ 、切土 $0.4 \%$ を示し、切土の被害率を基準にすると盛土は 6.3倍、切盛境界は5.0倍高い被害率である。同様に全壊と大規模半壊と半壊の合計（以下、半壊以上と呼 ぶ。）の被害率では盛土 $22.0 \%$ 、切盛境界16.7\%、切土10.7\%を示し、切土の被害率を基準にすると盛土 は2.1倍、切盛境界は1.6倍高い被害率である。これより、半壊以上の木造建物被害は計測震度との比例関 係が認められ、被害率は高い順に盛土、切盛境界、切土という結果が得られた。

\section{3. 2 P G A (地表面最大加速度) と被害率の関係}

(1) PGAと宅地被害率の関係

盛土・切盛境界・切土区分におけるPGAと宅地被害率の関係を図19に示す。ここに、今回得られた宅 地被害データは、PGAが300〜 700Galの範囲である。PGAの階級区分は、各階級のデータ数が全対象デー 夕数の $10 \%$ 以上となる範囲を任意に設定し、全データの $1 \%$ 程度以下の階級は除外した。図19より、PGA

（600～700Gal）で比較すると、宅地被害率は盛土 $4.1 \%$ 、切盛境界 $3.8 \%$ 、切土 $0.9 \%$ を示し、切土の被害 率を基準にすると盛土は4.6倍、切盛境界は4.2倍高い被害率である。また、宅地被害率は、切盛境界では PGAに比例して増加しているが、盛土と切土ではその傾向が認められない。

（2）PGA と木造建物被害率の関係

盛土・切盛境界・切土区分におけるPGAと木造建物被害率の関係を図20に示す。また、図21には全壊 被害と半損以上の被害について、近似曲線とともに示す。ここに、今回得られた建物被害データは、PGA が300〜700Galの範囲である。PGAの階級区分は、各階級のデータ数が全対象データ数の $10 \%$ 以上なる 範囲を任意に設定し、全データの $1 \%$ 程度以下の階級は除外した。図21より、PGA（600～700Gal）で比較 すると、全壊被害率は盛土1.9\%、切盛境界1.4\%、切土 $0.2 \%$ を示し、切土の被害率を基準にすると盛土は 9.5倍、切盛境界は7.0倍高い被害率である。同様に半壊以上の被害率では盛土18.9\%、切盛境界 $13.8 \%$ 、 切土 $7.7 \%$ を示し、切土の被害率を基準にすると盛土は2.5倍、切盛境界は1.8倍高い被害率である。また、 半壊以上の木造建物被害率では、盛土・切盛境界・切土のいずれもPGAに比例して増加する傾向が認め られるが、全壊ではいずれの場合もほぼ同じ被害率を示す。これより、半壊以上の木造建物被害はPGA との比例関係が認められ、被害率は高い順に盛土、切盛境界、切土という結果が得られた。しかしなが ら、全壊被害においては地盤区分に関係なく、今回のPGA（300～700Gal）の範囲内ではPGAとの相関性 は得られなかった。

\section{3.3 P G V（地表面最大速度）と被害率の関係}

(1) PGV と宅地被害率の関係

盛土・切盛境界・切土区分におけるPGV と宅地被害率の関係を図22に示す。ここに、今回得られた宅 地被害データは、PGVが30〜 $60 \mathrm{~cm} / \mathrm{s}$ の範囲である。PGVの階級区分は、各階級のデータ数が全対象デー 夕数の $10 \%$ 以上となる範囲を任意に設定し、全データの $1 \%$ 程度以下の階級は除外した。図 22 より、PGV $(50 \sim 60 \mathrm{~cm} / \mathrm{s})$ で比較すると、宅地被害率は盛土 $6.4 \%$ 、切盛境界 $4.6 \%$ 、切土 $1.7 \%$ を示し、切土の被害率 を基準にすると盛土は3.8倍、切盛境界は2.7倍高い被害率である。また、宅地被害率は、盛土・切盛境界・ 切土区分ともにばらつきが大きいが、近似曲線では比例関係が認められる。

(2) PGV と木造建物被害率の関係

盛土・切盛境界・切土区分におけるPGVと木造建物被害率の関係を図23に示す。また、図24には全壊 被害と半損以上の被害について、近似曲線とともに示す。ここに、今回得られた建物被害データは、PGV が30〜60（切盛境界は70） $\mathrm{cm} / \mathrm{s} の$ 範囲である。PGVの階級区分は、各階級のデータ数が全対象データ数 の $10 \%$ 以上となる範囲を任意に設定し、全データの $1 \%$ 程度以下の階級は除外した。図24より、PGV（50 $\sim 60 \mathrm{~cm} / \mathrm{s}$ ）で比較すると、全壊被害率は盛土 $3.0 \%$ 、切盛境界 $1.8 \%$ 、切土 $0.5 \%$ を示し、切土の被害率を基 準にすると盛土は6.0倍、切盛境界は3.6倍高い被害率である。同様に半壊以上の被害率では盛土21.7\%、 切盛境界 $16.1 \%$ 、切土 $10.3 \%$ を示し、切土の被害率を基準にすると盛土は2.1倍、切盛境界は1.6倍高い被 害率である。また、図24より、全壊および半壞以上の木造建物被害率は、盛土、切盛境界、切土ともに ばらつきが大きいがPGVに比例して増加する傾向が認められる。 


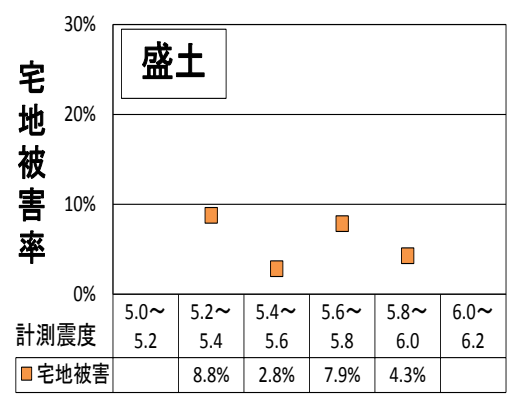

（1）盛土

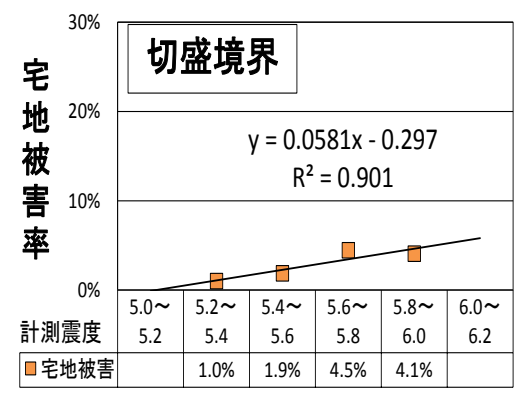

（2）切盛境界

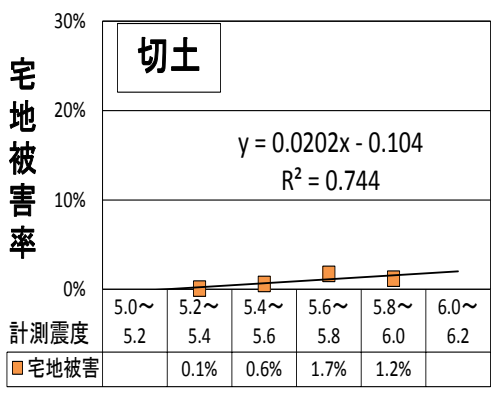

（3）切土

図 16 盛土・切盛境界・切土区分における計測震度と宅地被害率の関係

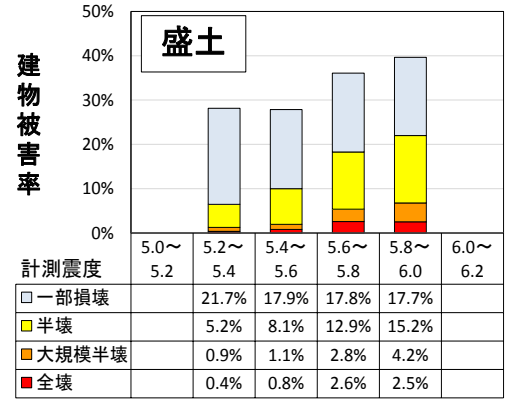

(1) 盛土

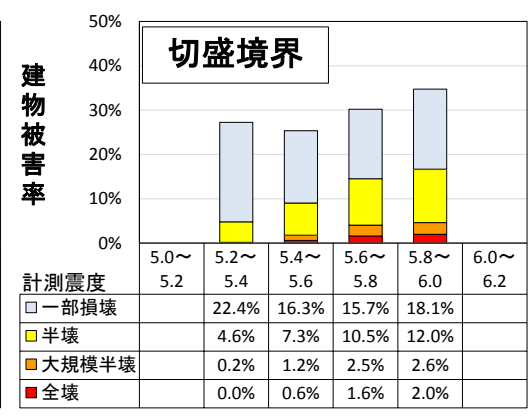

（2）切盛境界

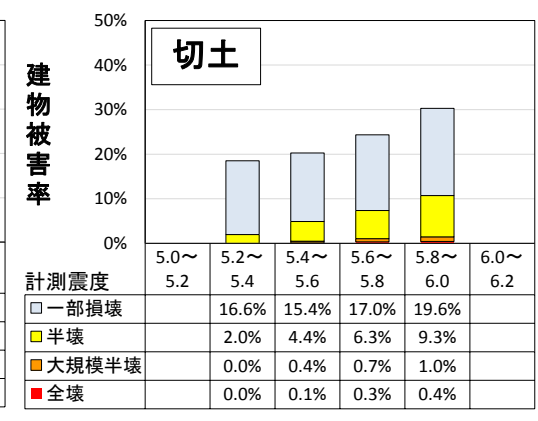

（3）切土

図 17 盛土・切盛境界・切土区分における計測震度と木造建物被害率の関係

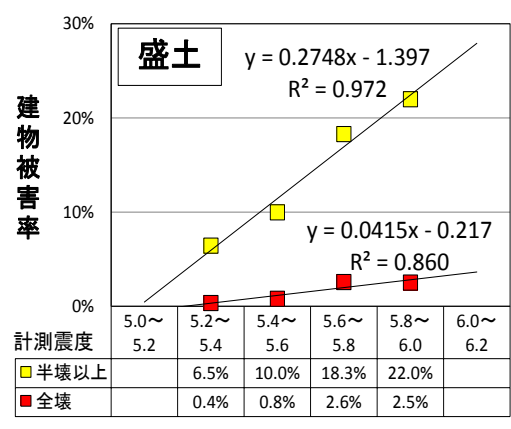

（1）盛土

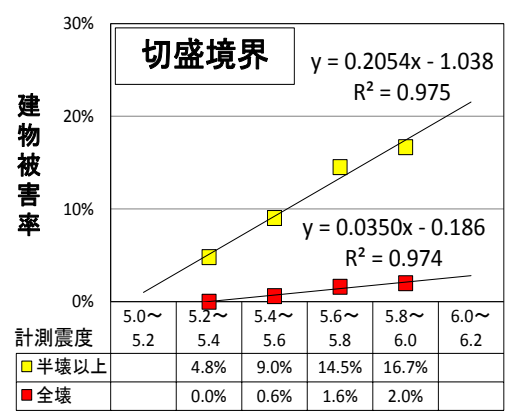

（2）切盛境界

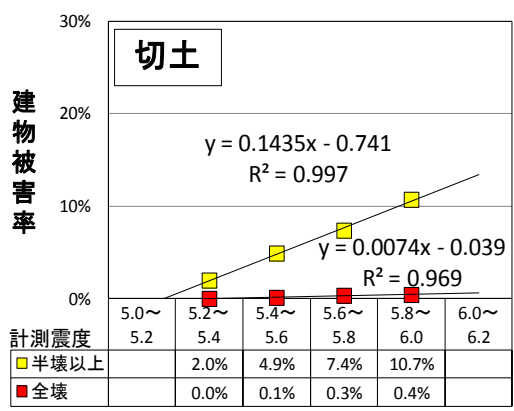

（3）切土

図 18 盛土 ·切盛境界 - 切土区分における計測震度と半壊以上の木造建物被害率の関係 


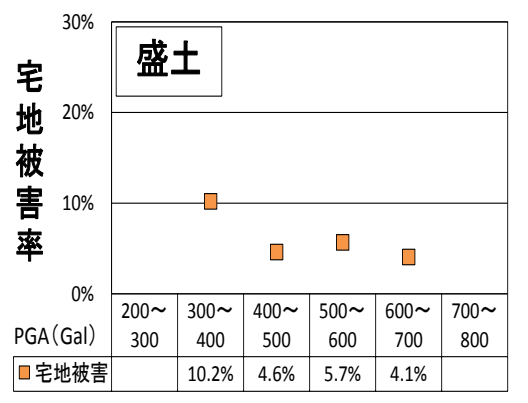

（1）盛土

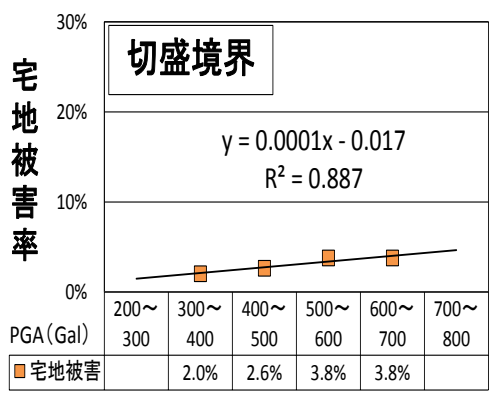

（2）切盛境界

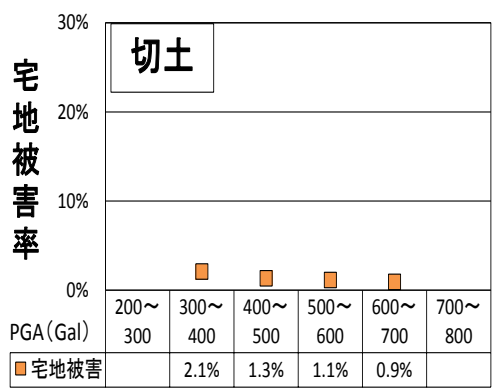

（3）切土

図 19 盛土・切盛境界・切土区分における PGA と宅地被害率の関係

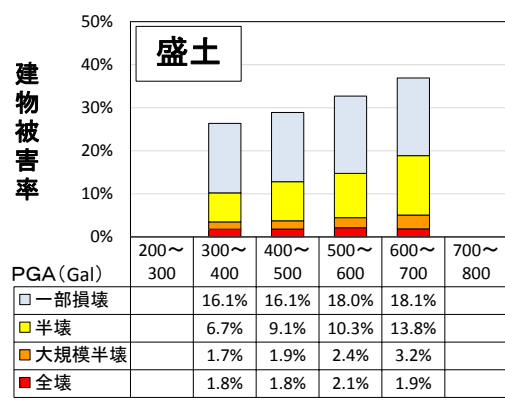

（1）盛土

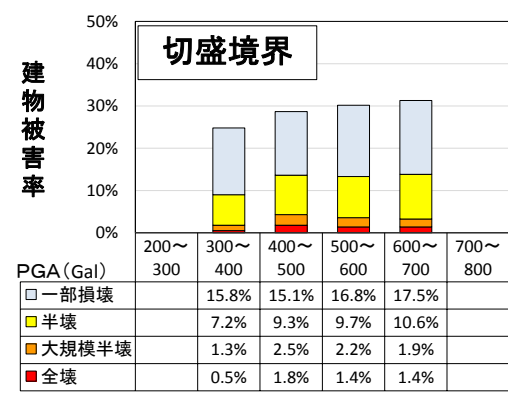

（2）切盛境界

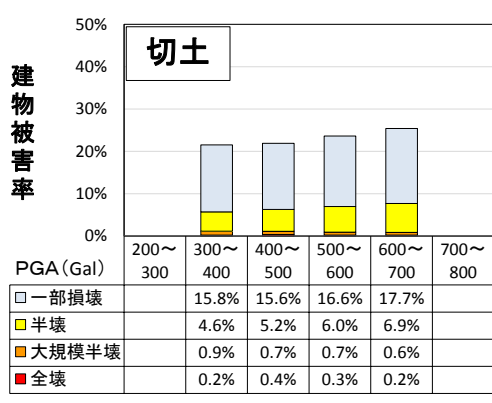

（3）切土

図 20 盛土・切盛境界・切土区分における PGA と木造建物被害率の関係

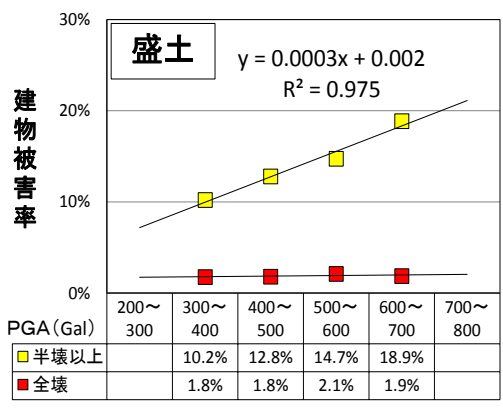

（1）盛土

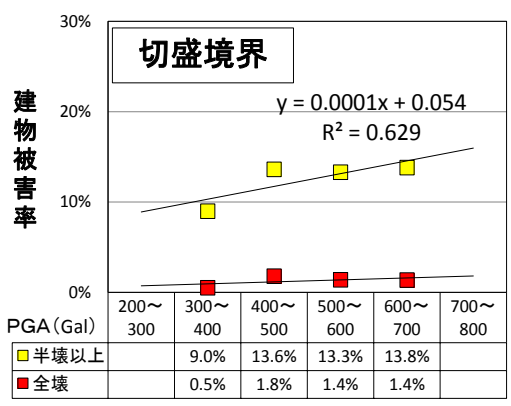

（2）切盛境界

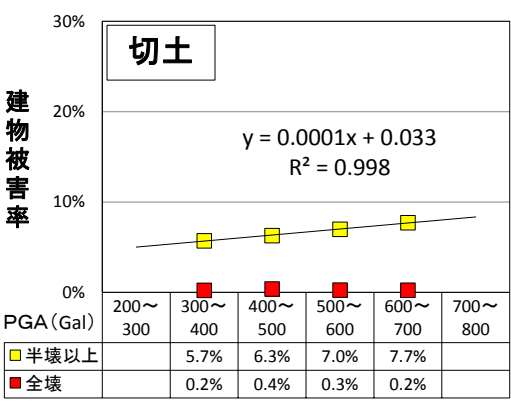

（3）切土

図 21 盛土・切盛境界・切土区分における PGA と半壊以上の木造建物被害率の関係 


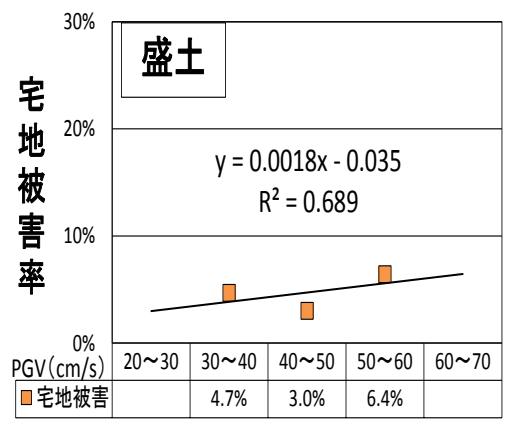

(1) 盛土

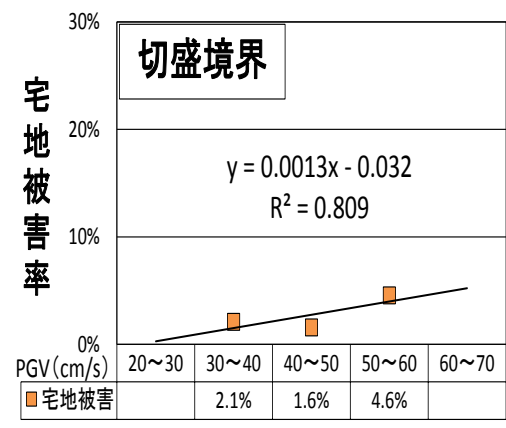

（2）切盛境界

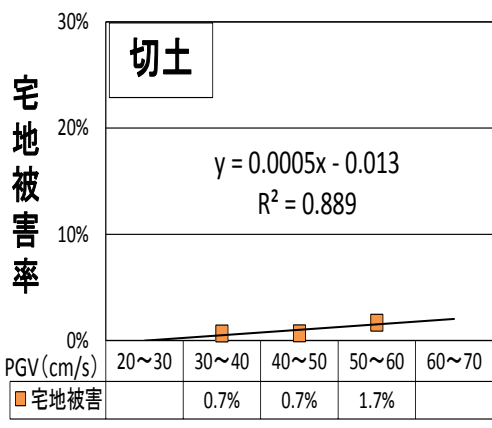

(3) 切土

図 22 盛土・切盛境界・切土区分における PGV と宅地被害率の関係

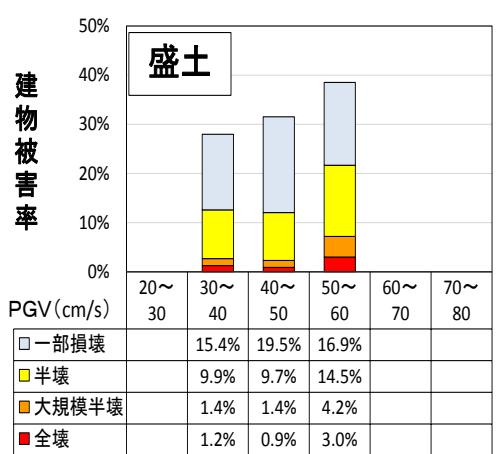

(1) 盛土

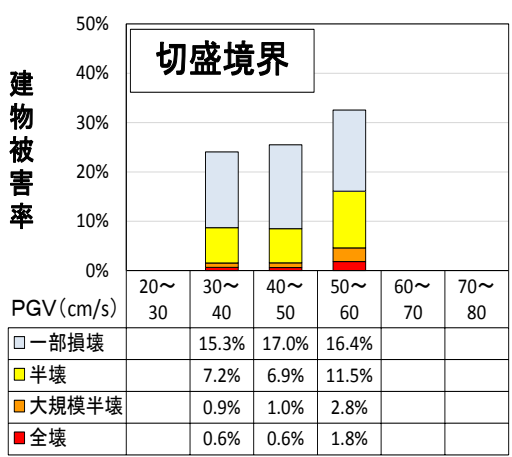

（2）切盛境界

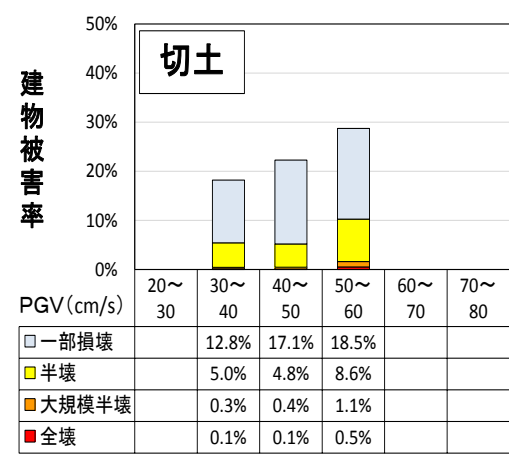

（3）切土

図 23 盛土・切盛境界・切土区分における PGV と木造建物被害率の関係

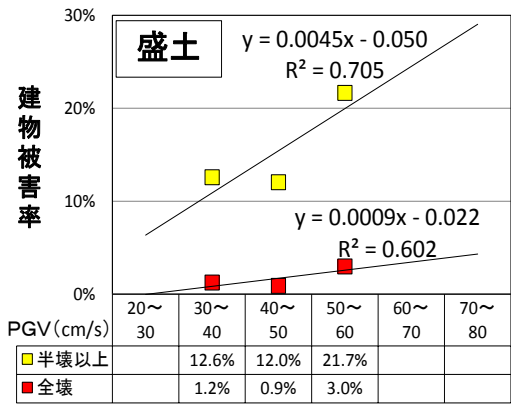

(1) 盛土

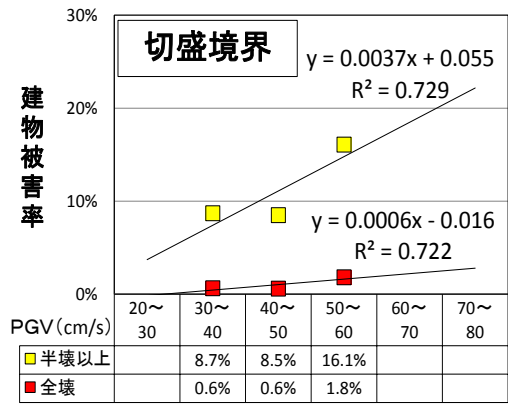

（2）切盛境界

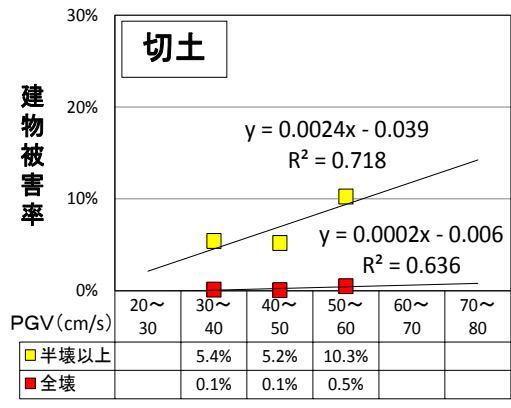

(3) 切土

図 24 盛土・切盛境界・切土区分における PGV と半壊以上の木造建物被害率の関係

\section{4 地盤特性別被害}

2011年東北地方太平洋沖地震における仙台市の造成宅地被害は、図25に示す7つの被害要因と、図26に 示すような被害形態を確認した。また、甚大な被害宅地箇所では盛土の耐震強度が非常に低い、すなわ ち、N值0〜4程度で盛土の締固め度が $85 \%$ 以下の非常に緩い締固め状態にあること（図27参照）、地下水 位が地表面下 $1 \sim 2 \mathrm{~m}$ 程度と非常に高いことを一部の地域で確認した。ここに、盛土材料は現地の地山を 構成寸る新第三紀の砂岩・泥岩・凝灰岩等の互層地盤の切土材料から構成されている。しかしながら、 
今回の宅地被害データおよび建物被害データと地盤物性值（土質、密度、強度、地下水位等）を関連づ けることができないため、ここでは、宅地の品質（耐震性）に影響する要因として「造成年代」、地震 時の盛土の滑動被害や不同沈下被害の要因として「現地盤勾配」、「旧地形勾配」および「盛土厚」を それぞれ選定して分析を行った。なお、既存知見では盛土の滑動を三次元的に考えて盛土幅の影響も述 ベているが、今回現地調査で確認された滑動被害は大部分が盛土上層部の一部分における変形被害であ るため、盛土幅の影響は考慮しなかった。

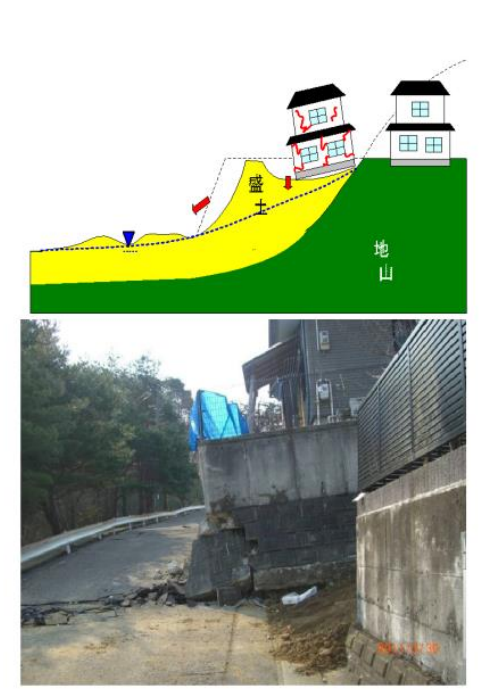

a. 谷埋め盛土の滑動に起因

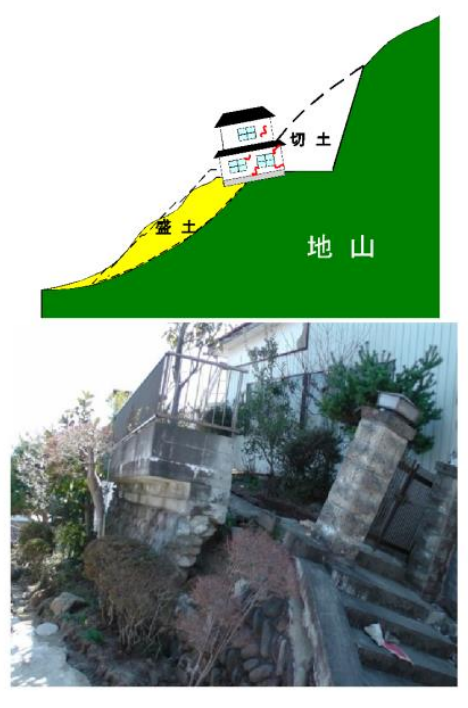

b. 腹付け盛土の滑動に起因

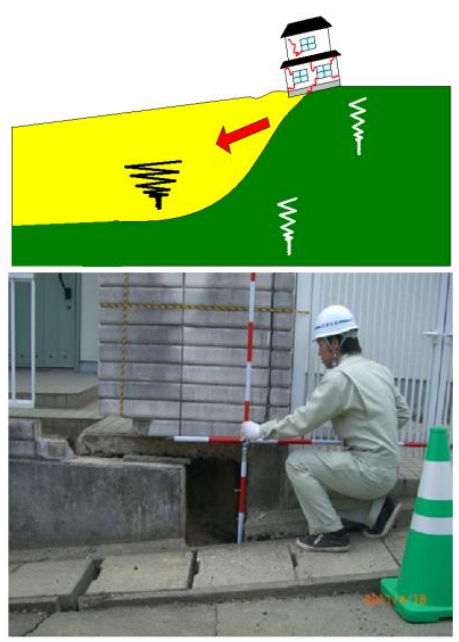

c. 切盛境界に起因

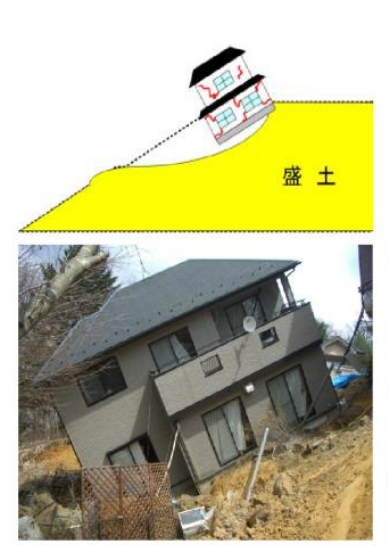

d. のり面の安定性 不足に起因

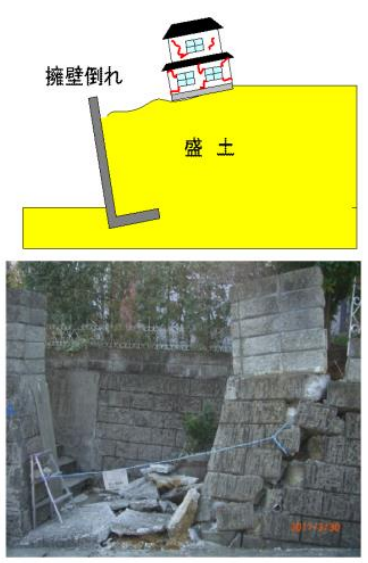

e. 擁壁の安定性 不足に起因

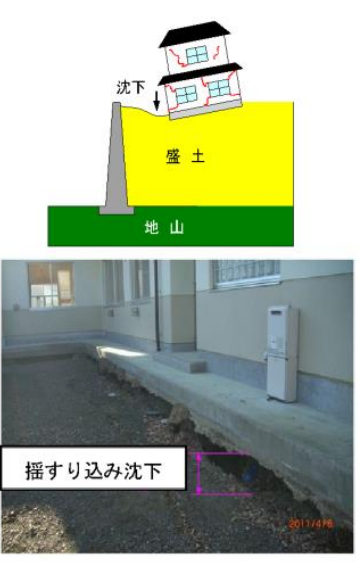

f. 緩い盛土状態 に起因

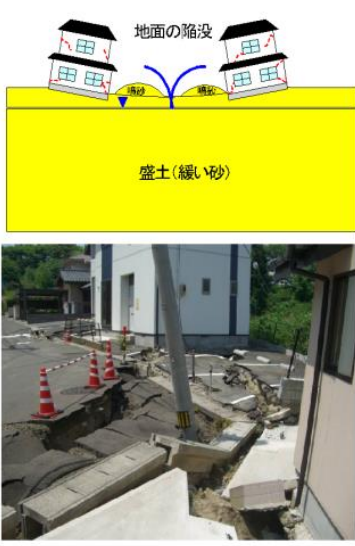

g. 地盤の液状化 に起因

図25＼cjkstart仙台市における造成宅地の被害要因 


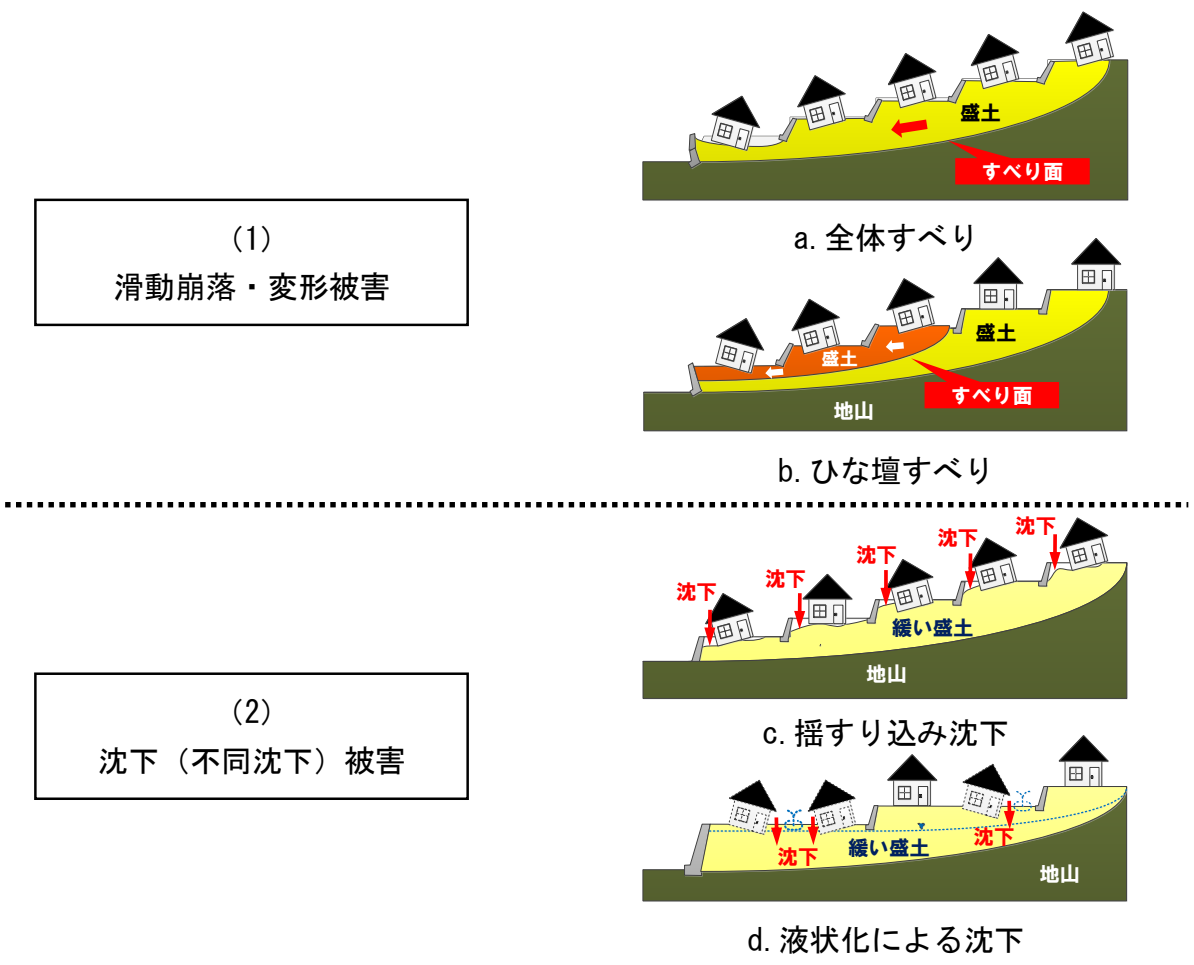

(3)

擁壁被害

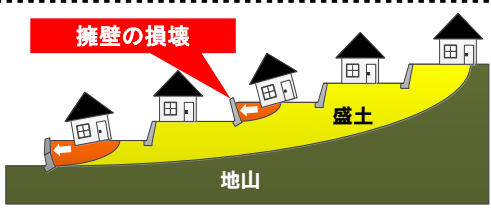

e. 擁壁の安定性不足による変状

図26仙台市における造成宅地の被害形態

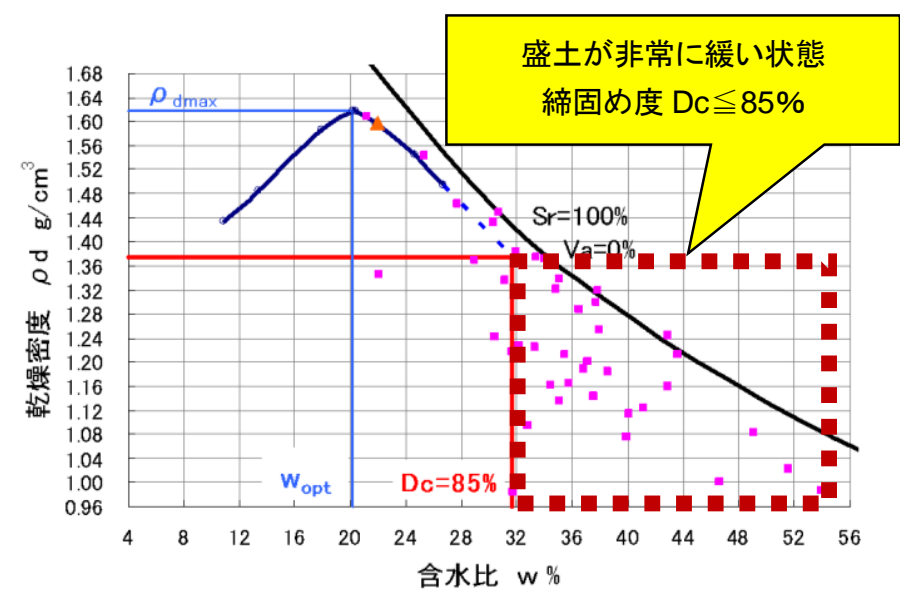

図27甚大な被害地区の盛土の締固め度の例 ${ }^{14)}$ 


\section{4.1 造成年代と被害率の関係}

（1）造成年代と宅地被害率の関係

盛土・切盛境界・切土区分における造成年代と宅地被害の関係を図28に示す。図28(a)は被害宅地数の 頻度分布、図28(b)は宅地被害率、図28(c)は被害宅地数を新しい年代から順に累計した累積頻度分布であ る。図28(a)より、宅地被害は盛土・切盛境界・切土のいずれも平成元年付近以前の造成地で発生してお り、特に昭和 40 年付近以前の造成地で被害数が卓越している。また、図28(b)より、宅地被害率は盛土・ 切盛境界・切土ともに、昭和40年付近を境としてその前後で被害率が大きく変化している。盛土では、 昭和 40 年以降の宅地被害率が概ね $25 \%$ 以下であるのに対して、昭和 40 年以前では $10 \%$ 以の被害率を示す。 同様に、切盛境界では昭和 40 年以降が概衫 $4 \%$ 以下で昭和 40 年以前では約 $6 \%$ 、切土では昭和 40 年以降が 概ね $1 \%$ 以下で昭和 40 年以前では約 $2 \%$ の宅地被害率をそれぞれ示す。また、切土の被害率を基準にする と、盛土は昭和 40 年以前・以後ともに約 5 倍、切盛境界では昭和 40 年以降で約4倍、昭和 40 年以前で約3倍 の宅地被害率を示す。

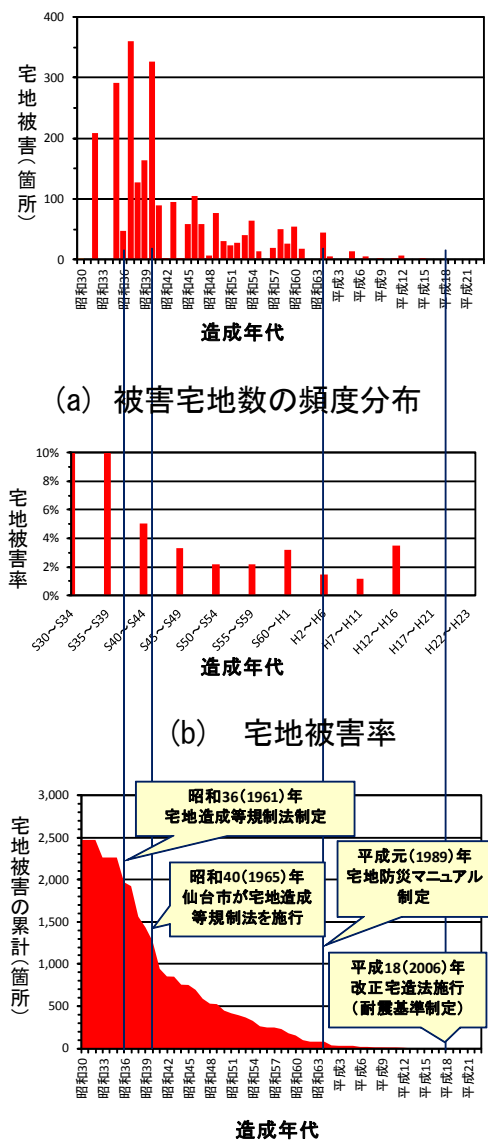

(c) 被害宅地の累積頻度分布

（1）盛土

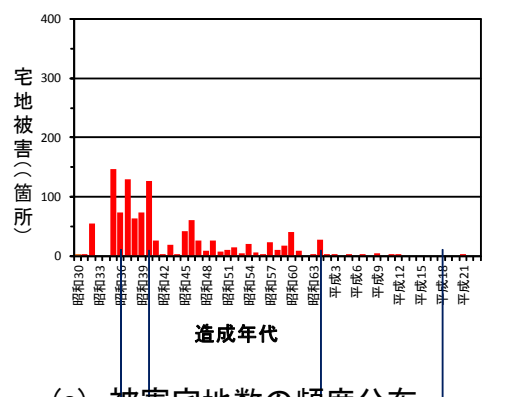

(a) 被害宅地数の頻度分布

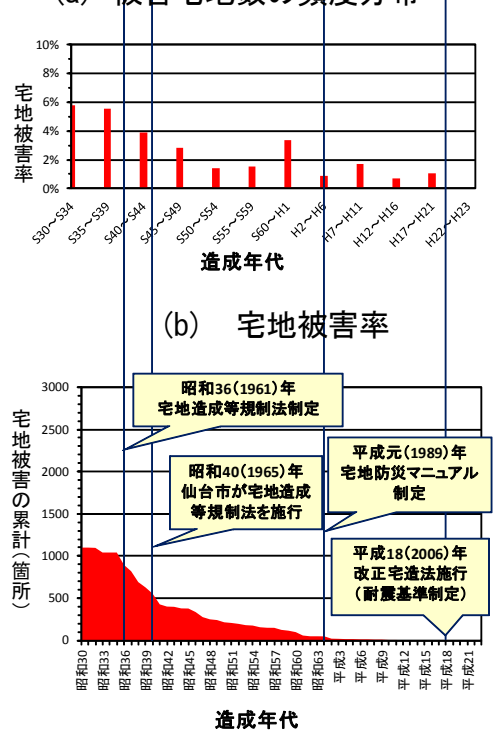

（c）被害宅地の累積頻度分布

（2）切盛境界

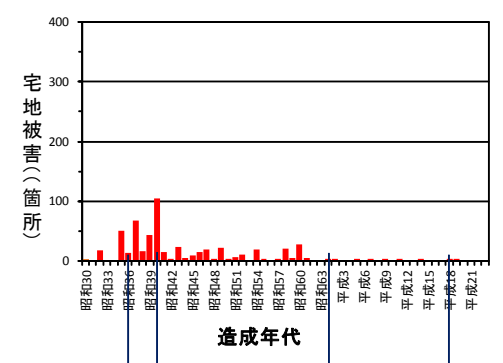

（a）被害宅地数の頻度分布

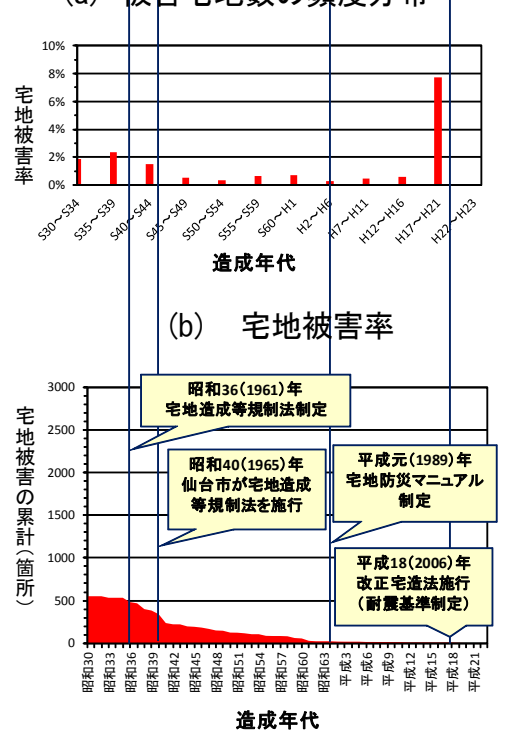

（c） 被害宅地の累積頻度分布

(3) 切土

図 28 造成年代と宅地被害の関係 
（2）造成年代と木造建物被害率の関係

盛土・切盛境界・切土区分における造成年代と木造建物被害の関係を図29に示す。図29(a)は全壊、大 規模半壊、半壞、一部損壊の各種被害数に無被害建物数を加えた各造成年代の建物総数を示すものであ る。図29(b)は全壊における木造建物被害率、図29(c)は全壊における木造建物被害数を新しい年代から順 に累計した累積頻度分布である。図29(a)、(c)より、木造建物被害（特に全壊）は盛土・切盛境界・切土 のいずれも平成元年付近以前の造成地で発生している。また、図29(b)より、全壊被害率は盛土・切盛境 界・切土ともに宅地被害と同様に、昭和40年付近を境としてその前後で被害率が変化している。盛土で

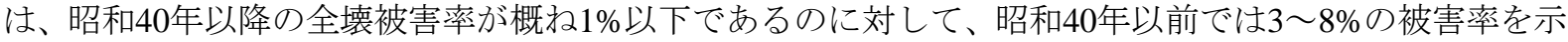
す。同様に、切盛境界では昭和 40 年以降が概衫 $1 \%$ 以下で昭和 40 年以前では約 $2 \%$ 、切土では昭和 40 年以降 が概ね $0.5 \%$ 以下で昭和 40 年以前では約 $1 \%$ の全壊被害率をそれぞれ示す。また、切土の被害率を基準にす ると、盛土は昭和 40 年以降で約 2 倍、昭和 40 年以前では3 8倍、切盛境界では昭和 40 年以前・以後ともに 約2倍の全壊被害率を示す。

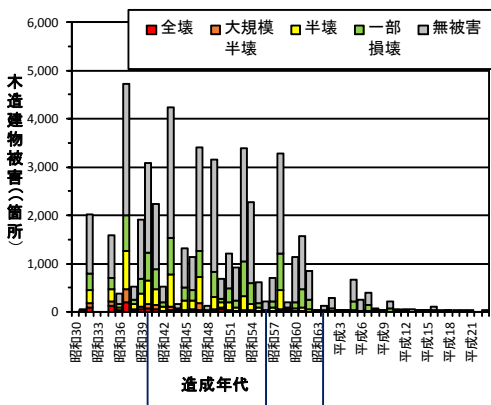

（a）建物総数と被害建物数

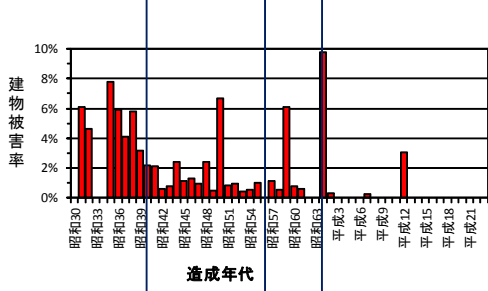

（b）木造建物被害率（全壊）

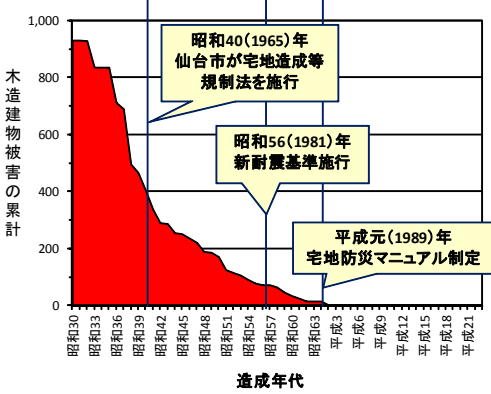

（c）被害建物の累積分布（全壊）

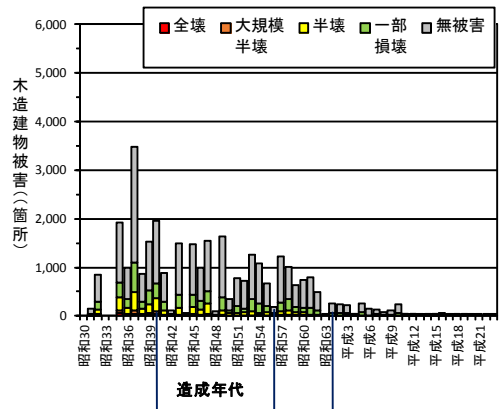

(a) 建物総数と被害建物数

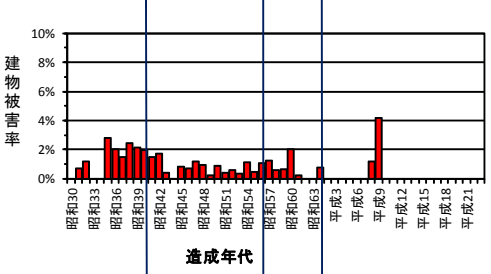

（b）木造建物被害率（全壊）

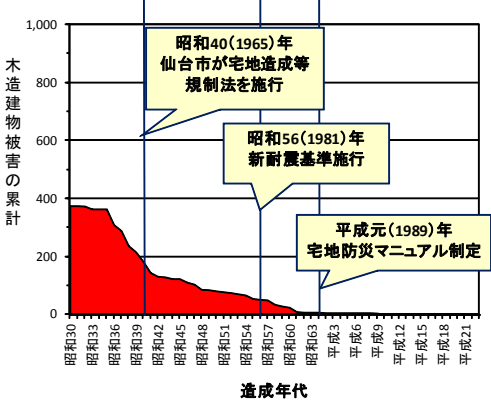

（c）被害建物の累積分布（全壊）

（2）切盛境界

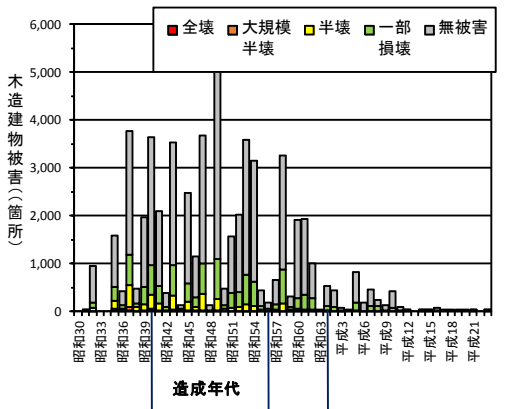

（a）建物総数亡被害建物数

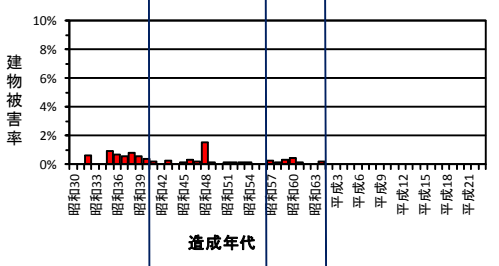

（b）木造建物被害率（全壊）

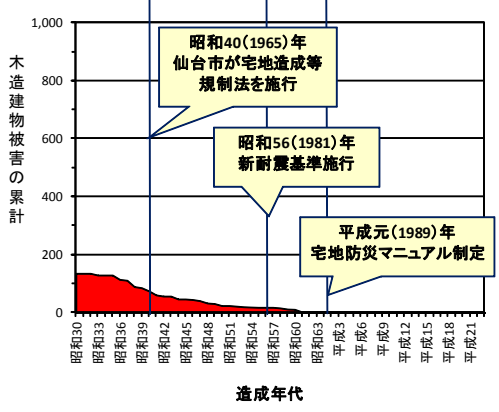

（c） 被害建物の累積分布（全壊）

（3）切土

図 29 造成年代と木造建物被害の関係 


\section{4.2 現地盤勾配と被害率の関係}

(1) 現地盤勾配と宅地被害率の関係

盛土・切盛境界・切土区分における現地盤勾配と宅地被害の関係を図30に示寸。また、図30の傾向か ら、現地盤勾配を6度未満、6〜10度、10度以上の3つに区分した場合の宅地被害率をまとめて図31に示す。 図31より、盛土・切盛境界・切土ともに、現地盤勾配が急になるほど宅地被害率は大きくなっている。 盛土では、現地盤勾配6度未満を基準にすると、6〜10度では2.8倍、10度以上では4.5倍の被害率を示す。 同様に、切盛境界の場合は6〜10度では2.8倍、10度以上では5.1倍、切土の場合は6〜10度では3.5倍、10度 以上では8.0倍を示す。また、現地盤勾配における宅地被害率は、盛土、切盛境界、切土の順で高く、切 土の被害率を基準にすると、盛土の被害率は6度未満で5.3倍、6 10度で4.3倍、10度以上で3.0倍を示す。 同様に、切盛境界の被害率は6度未満で2.8倍、6〜10度で2.3倍、10度以上で1.8倍を示す。

なお、現地盤勾配は10度までは宅地周辺のほぼ一様な勾配を示すが、10度以上の勾配の場合は宅地の 周囲に10度を超えるのり面や高い擁壁等が存在することを意味している。

（2）現地盤勾配と木造建物被害率（全壊）の関係

盛土・切盛境界・切土区分における現地盤勾配と木造建物被害（全壊）の関係を図32に示す。また、 図32の傾向から、現地盤勾配を6度未満、6 10度、10度以上の3つに区分した場合の木造建物被害率（全 壊）をまとめて図32に示す。図33より、盛土・切盛境界・切土ともに、現地盤勾配が急になるほど全壊 被害率は大きくなっている。盛土では、現地盤勾配6度未満を基準にすると、6 10度では2.1倍、10度以 上では3.2倍の被害率を示す。同様に、切盛境界の場合は6〜10度では1.8倍、10度以上では2.8倍、切土の 場合は6〜10度では2.0倍、10度以上では5.0倍を示す。

また、現地盤勾配における全壊被害率は、盛土、切盛境界、切土の順で高く、切土の被害率を基準に すると、盛土の被害率は6度未満で7.5倍、6 10度で8.0倍、10度以上で4.8倍を示す。同様に、切盛境界の 被害率は6度未満で4.5倍、6〜10度で4.0倍、10度以上で2.5倍を示す。

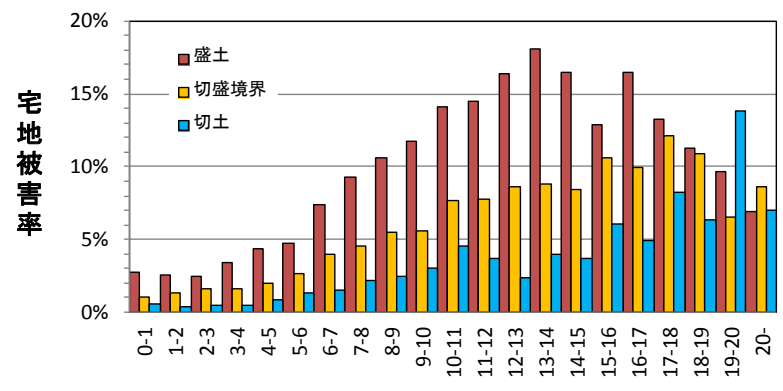

現地盤勾配(度)

図 30 現地盤勾配と宅地被害率の関係

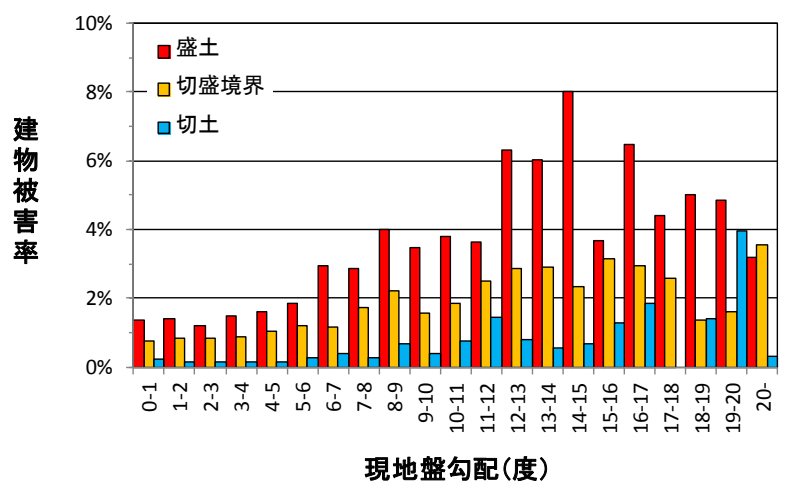

図 32 現地盤勾配と木造全壊被害率の関係

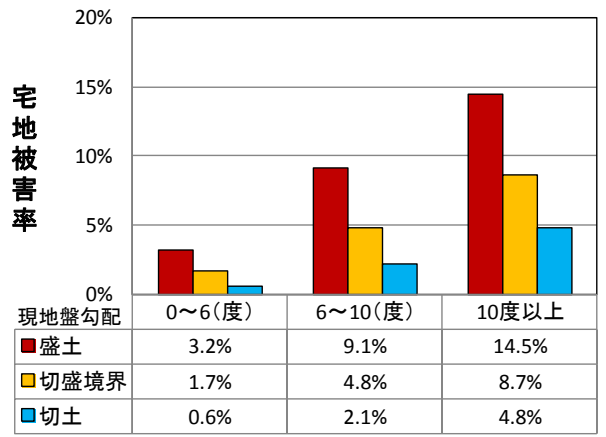

図 31 現地盤勾配区分と宅地被害率の関係

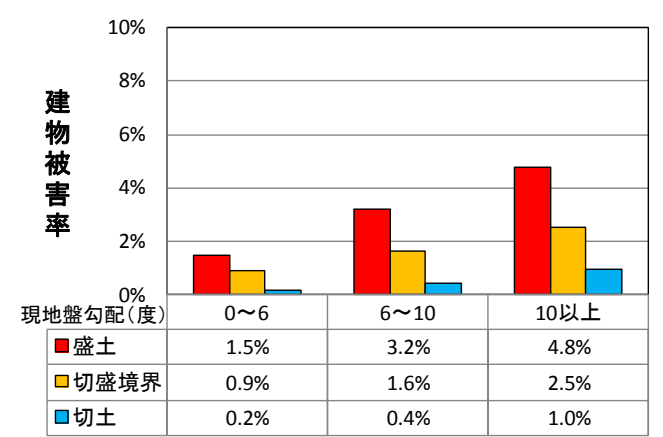

図 33 現地盤勾配区分と木造全壊被害率の関係 


\subsection{3 旧地形勾配と被害率の関係}

（1）旧地形勾配と宅地被害の関係

盛土および切盛境界における旧地形勾配と宅地被害の関係を、図34に示寸。盛土の宅地被害率は図 34(a)より、旧地形勾配が急になるほどやや大きくなる傾向が認められ、3度未満では被害率2\%程度、3〜 11度では同4\%程度、11度以上では同5〜7\%を示す。また、切盛境界の宅地被害率は図34(b)より、旧地形 勾配が急になるほど大きくなる傾向が認められ、5度未満では被害率1\%程度、5９度では同2\%程度、9 度以上では同4〜6\%を示す。

（2）旧地形勾配と木造建物被害（全壊）の関係

盛土および切盛境界における旧地形勾配と木造建物被害（全壊）の関係を、図35に示寸。同図より、 盛土および切盛境界における全壊被害は、旧地形勾配と明瞭な比例関係にはなく、旧地形勾配に関わら ず全壊被害率は概ね 21 ～2\%を示す。

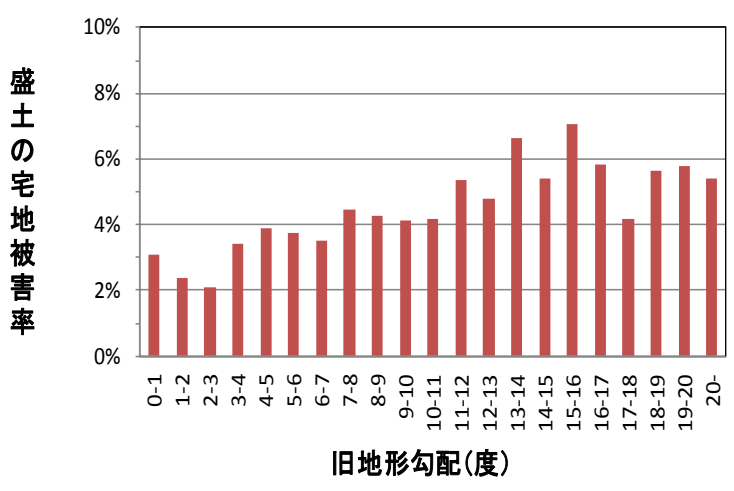

（a）盛土

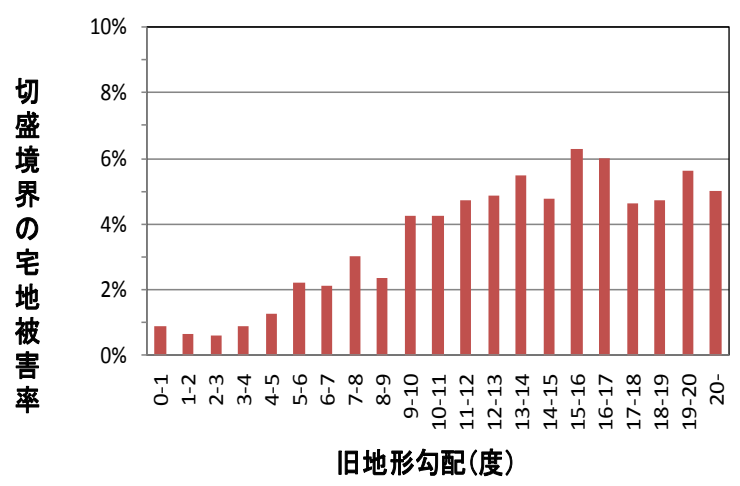

(b) 切盛境界

図 34 旧地形勾配と宅地被害率の関係

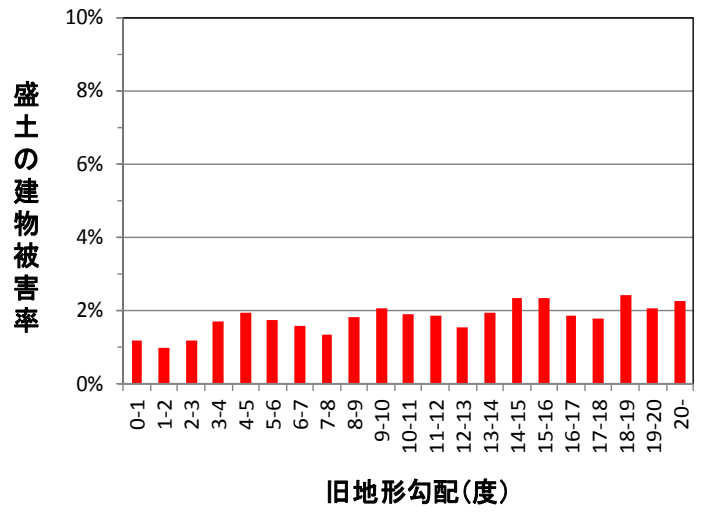

(a) 盛土

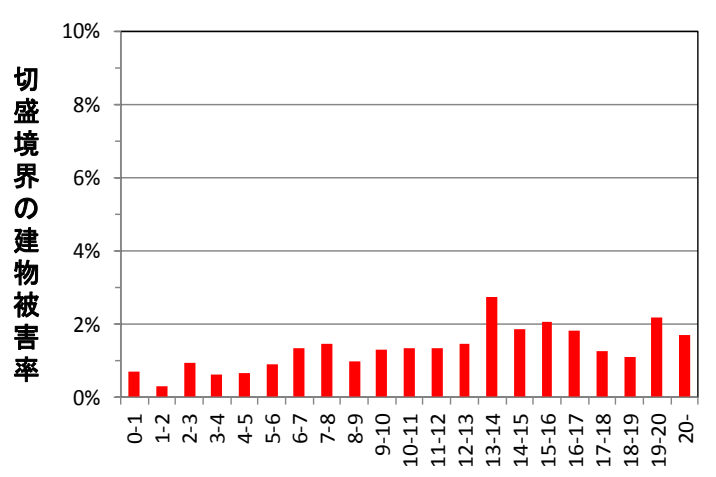

旧地形勾配(度)

(b) 切盛境界

\section{図 35 旧地形勾配と木造全壊被害率の関係}

\section{4.4 盛土厚と被害率の関係}

（1）盛土厚と宅地被害の関係

宅地被害箇所の盛土厚とは、仙台市都市計画図上の被災宅地における概ね中心付近を任意に指定した 座標において、新旧地形図の差分から抽出した厚さである。盛土厚と宅地被害の関係を図 36 に示す。図 36(a)は宅地被害数を示すものであるが、盛土厚が薄いほど宅地被害数が多い傾向が認められる。しかし ながら、図 36(b)の宅地被害率では、盛土厚が $8 \mathrm{~m}$ 付近までは盛土厚に比例して宅地被害率が増加する傾 向が認められるが、盛土厚 $8 \mathrm{~m}$ よりも厚くなると宅地被害率は同じかやや低くなる傾向が認められる。 
（2）盛土厚と木造建物被害（全壊）の関係

木造建物被害箇所の盛土厚とは、被害建物の住所座標 ${ }^{15)}$ における盛土厚で、新旧地形図の差分から 抽出した厚さである。盛土厚と木造建物被害（全壊）の関係を図 37 に示す。図 37(a) は木造全壊建物数 を示寸ものであるが、宅地被害と同様に、盛土厚が薄いほど木造全壊建物数が多い傾向が認められる。 しかしながら、図 37(b)の木造全壊建物被害率では、盛土厚が $6 \mathrm{~m}$ 付近までは盛土厚に比例して被害率 が増加する傾向が認められるが、盛土厚 $6 \mathrm{~m}$ よりも厚くなると木造全壞建物被害率は同じかやや低くな る傾向が認められる。

（3）盛土厚と現地盤勾配の関係

盛土厚と現地盤勾配の関係を図 38 に示す。図 38(a)は宅地被害、図 38(b)は木造建物被害（全壊）の盛 土厚と現地盤勾配の関係をそれぞれ示寸ものである。同図より、宅地被害および木造建物被害（全壊） ともに回帰式の決定係数 $\mathrm{R}^{2}$ は 0.05 を示し、盛土厚と現地盤勾配の相関性は非常に低い。

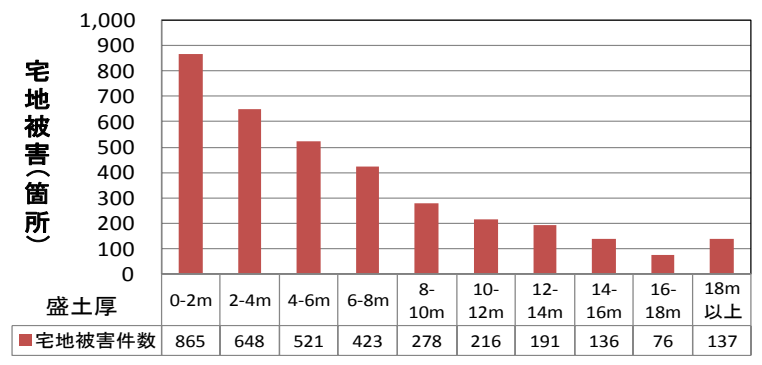

（a）盛土厚と宅地被害数

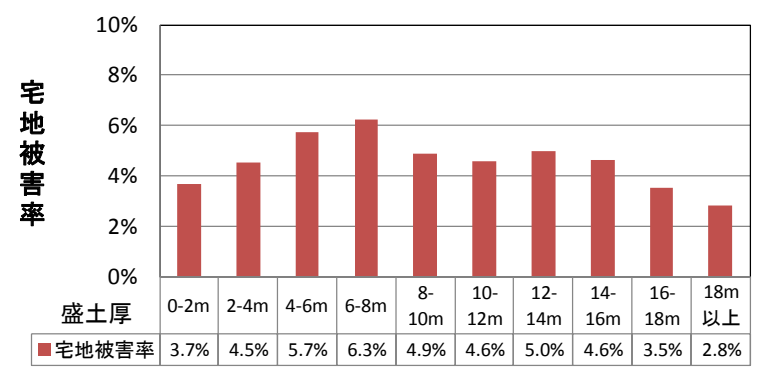

(b) 盛土厚と宅地被害率

図 36 盛土厚と宅地被害率の関係

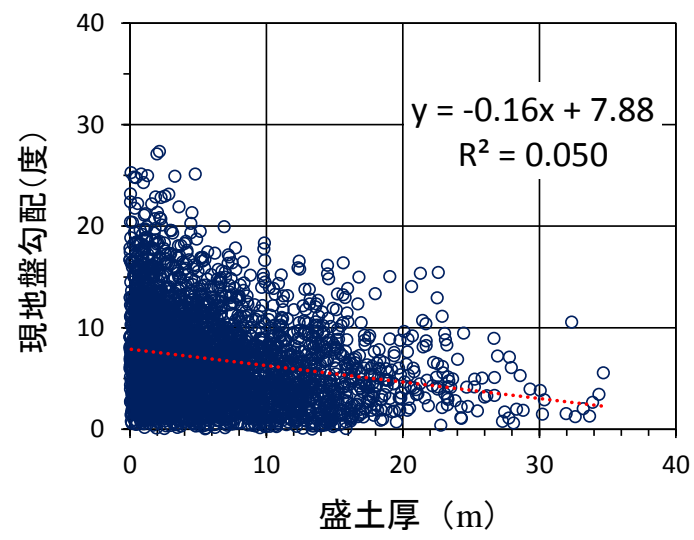

(a) 宅地被害

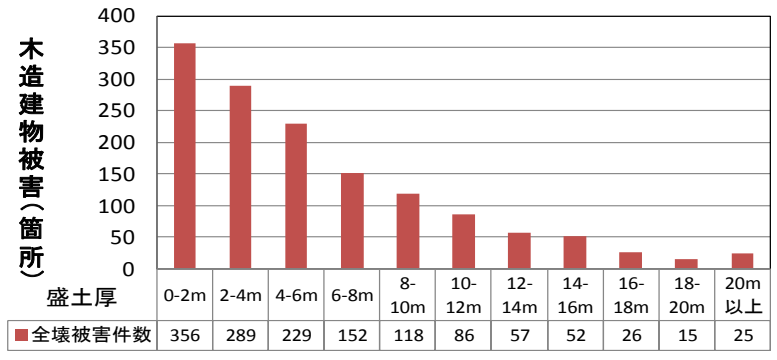

（a）盛土厚と木造全壊建物数

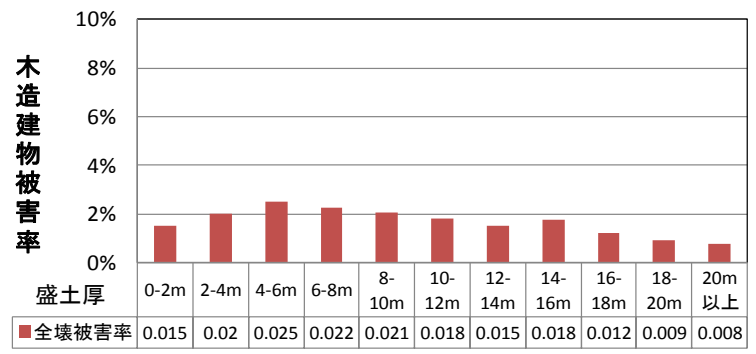

（b）盛土厚と木造全壊被害率

\section{図 37 盛土厚と木造全壊被害率の関係}

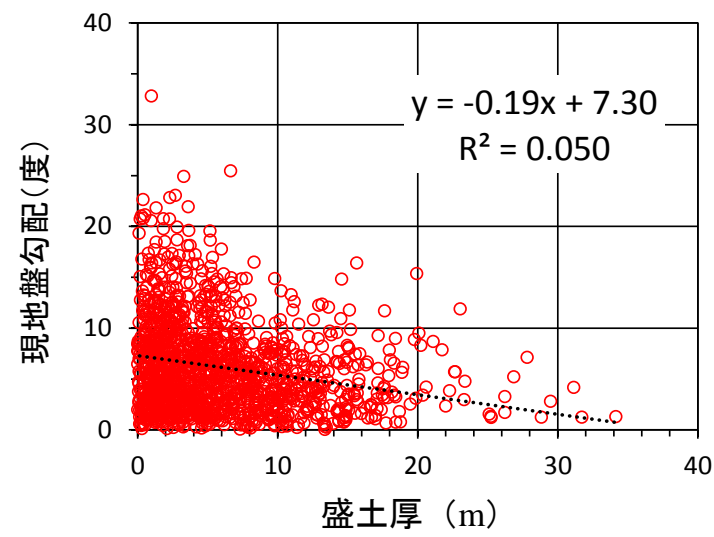

（b）木造建物被害（全壊）

図 38 盛土厚と現地盤勾配の関係 


\section{5 建物特性別被害}

\section{5.1 建築年代と木造建物被害率の関係}

盛土・切盛境界・切土区分における建築年代別木造建物被害割合の関係を図39に示寸。同図における 上段(a)は各建築年における木造建物被害数、中段(b)は各建築年における木造建物被害の割合、下段(c)は 建築年の新しい方から順に木造建物被害数を累積したものである。なお、各建築年における無被害数が 不明であるので、ここでは、被害全体を母数として被害の割合を求めた。

各建築年における木造建物被害については、図39(b)より、盛土・切盛境界・切土ともに、建築年が古 いほど半壊以上の被害の割合が高くなる傾向が得られた。

昭和56年の新而震基準施行前と施行後の木造建物被害については、図39において、大規模半壊以上の 被害で見ると、昭和55年以前の建築年の被害は、盛土・切盛境界・切土ともに、昭和56年以降と比較し て発生頻度も被害割合も高い傾向が認められる。また、全壊被害の割合について昭和55年以前と昭和56 年以降で比較した結果を表3に示す。表3より、昭和56年以降の被害割合を基準にすると、昭和55年以前 の被害の割合は、盛土では2.4倍、切盛境界では3.2倍、切土では4.0倍を示す。さらに、切土の被害割合を 基準にすると、盛土では昭和55年以前で4.8倍、昭和56年以降で8.0倍、切盛境界では昭和55年以前で 4.0 倍、昭和56年以降で5.0倍をそれぞれ示す。

表 3 木造建物（全壊）被害の割合

\begin{tabular}{|c|c|c|c|c|c|c|c|c|}
\hline \multirow[b]{2}{*}{ 地盤区分 } & \multicolumn{4}{|c|}{ 昭和 55 年以前 } & \multicolumn{3}{|c|}{ 昭和56年以降 } & \multirow{2}{*}{$\begin{array}{c}\text { 木造建物 } \\
\text { 建物総数 } \\
\text { （箇所） }\end{array}$} \\
\hline & $\begin{array}{l}\text { 被害数 } \\
\text { (箇所) }\end{array}$ & 被害割合 & \begin{tabular}{|l} 
昭和56年以降被害 \\
割合に対する割合
\end{tabular} & $\begin{array}{c}\text { 切土を基準とした } \\
\text { 被害割合 }\end{array}$ & $\begin{array}{l}\text { 被害数 } \\
\text { (箇所) }\end{array}$ & 被害割合 & $\begin{array}{c}\text { 切土を基準とした } \\
\text { 被害割合 }\end{array}$ & \\
\hline 盛土 & 707 & $3.8 \%$ & 2.4 & 4.8 & 298 & $1.6 \%$ & 8.0 & 18,631 \\
\hline 切盛境界 & 420 & $3.2 \%$ & 3.2 & 4.0 & 129 & $1.0 \%$ & 5.0 & 13,298 \\
\hline 切土 & 112 & $0.8 \%$ & 4.0 & 1.0 & 34 & $0.2 \%$ & 1.0 & 14,218 \\
\hline
\end{tabular}

※各建築年における木造建物の無被害数が不明なため、上記被害割合は木造建物被害総数を母数とした割合を示す.

\section{5.2 基礎の被害率}

木造建物被害データのうち基礎の損傷率が75\%以上の被害は全壊として判定されている5)。このため、 木造建物の全壊被害と基礎の損傷率が75\%以上の被害の関係を調べて図40に示す。また同図には、基礎 の被害率 $75 \%$ 以上の箇所数と全壊被害数に対する同被害率を併記して示す。図40より、基礎の被害率 $75 \%$ 以上の被害箇所の被害率は、切土を基準とすると、盛土は1.2倍、切盛境界は0.9倍を示す。 


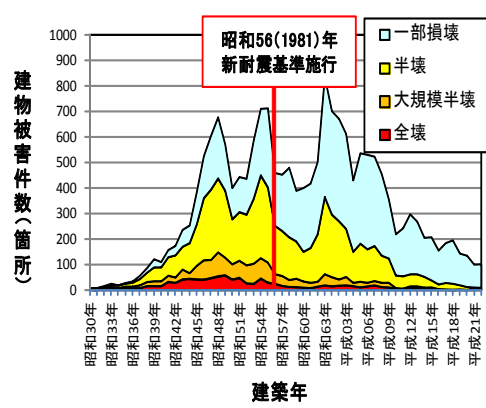

（a）建物被害の頻度分布

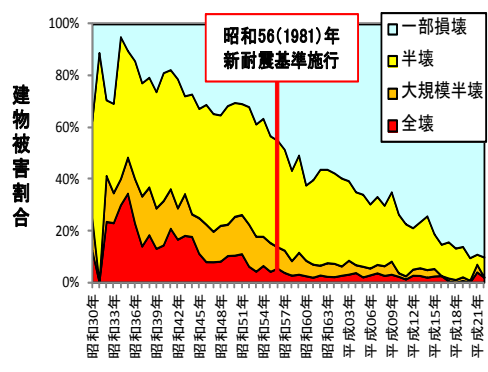

建築年

（b）建物被害の割合

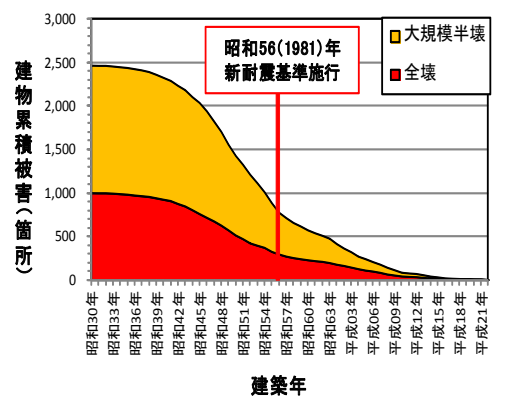

（c）建物被害の累計頻度分布

(1) 盛土

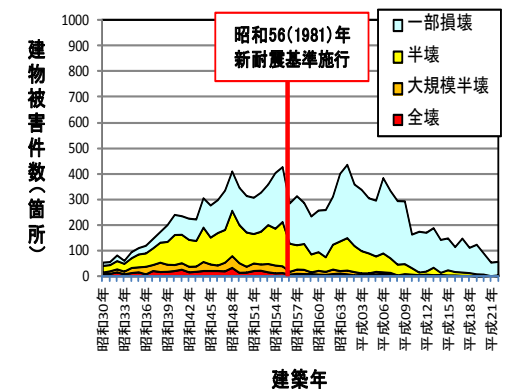

（a）建物被害の頻度分布

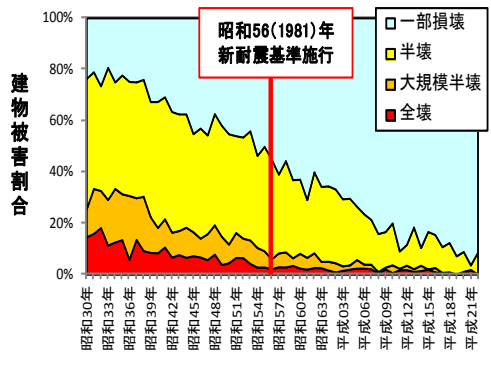

建筑年

(b) 建物被害の割合

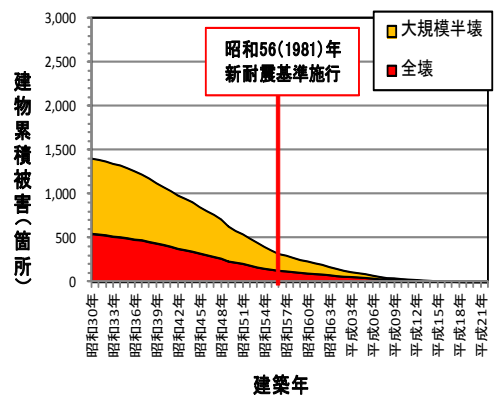

（c）建物被害の累計頻度分布

（2）切盛境界

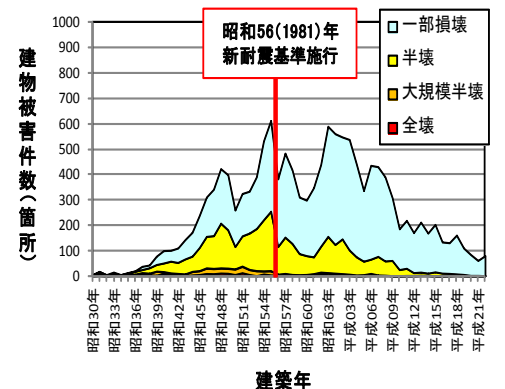

（a）建物被害の頻度分布

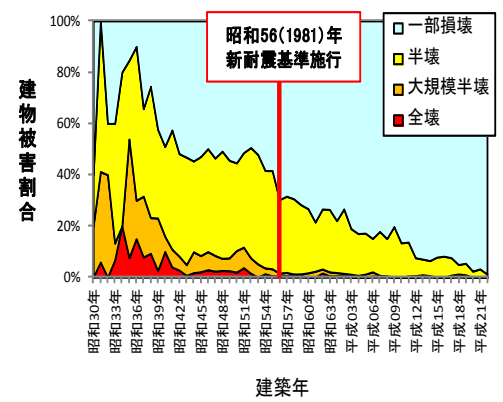

(b) 建物被害の割合

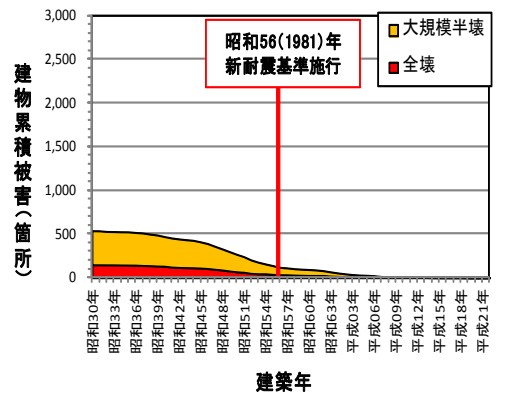

(c) 建物被害の累計頻度分布

（3）切土

図 39 切土・盛土・切盛境界区分における建築年代別木造建物被害割合の関係

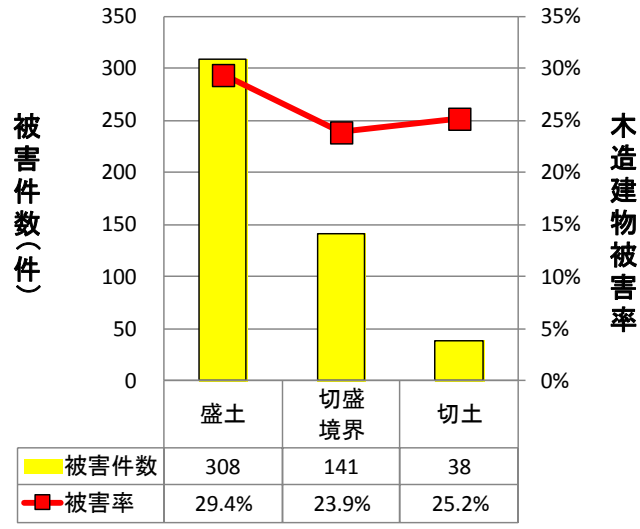

図 40 基礎の被害率 75\%以上の被害 


\section{4. 考察}

\section{1 宅地被害率および木造建物被害率}

切盛して造成された宅地における宅地および木造建物被害は、これまで地盤変状が起こりやすい切盛 境界で主に発生し盛土や切土上の被害は少ないと考える人も多かった。しかしながら、今回の被害分析 により、宅地被害率および木造建物被害率は共に切盛境界よりも盛土の方が高いことが判明した。この 理由については、盛土上では6つの被害要因、寸なわち、(1)谷埋め盛土の滑動に起因するもの、(2)腹付 け盛土の滑動に起因するもの、(3)のり面の安定性不足に起因するもの、(4)擁壁の安定性不足に起因する もの、(5)緩い盛土状態（摇寸り込み沈下）に起因するもの、(6)地盤の液状化に起因するもの、が単独も しくは複合して発生したためと考えられる（図25）。

図14と図15より、宅地被害率と木造建物被害率（大規模半壊と全壊の合計）はほぼ同じ值と傾向を示 し、大規模半壊以上の建物被害は宅地地盤の変状の影響が高いことが推察される。

\section{2 地震動特性別被害}

\section{2.1 計測震度と被害率の関係}

計測震度と宅地被害率の関係では、宅地被害率は切盛境界と切土では計測震度に比例して増加する傾 向が認められるが、盛土では計測震度の増加との比例関係は認められない（図16）。この理由としては、 宅地地盤の被害は、切土では擁壁被害、切盛境界では擁壁被害と切盛境界での段差等による被害といっ たいわゆる構造物被害であるため、擁壁または地盤における地震時せん断強度と地震動の大きさとの関 係が明瞭に現れたものと考えられる。また、盛土については、計測震度5.2〜 5.4という比較的小さな震度 であっても、今回の地震動の継続時間が長かったことによる液状化の発生や非常に緩い盛土の摇すり込 み沈下等が発生したために被害が多く発生し、今回測定された計測震度（5.2～6.0）の範囲内では明瞭な 関係が得られなかったものと推測される。

\section{2. 2 P G A と被害率の関係}

PGAと宅地被害率の関係では、宅地被害率は切盛境界ではPGAに比例して増加しているが、盛土と切 土ではその傾向が認められない（図19）。このことから、今回のPGA（300～700Gal）の範囲内ではPGA は切盛境界の宅地地盤の被害に対しては影響が大きいと言える。盛土と切土上の宅地地盤に対して正の 相関が認められなかったのは、PGAが比較的短周期の地震動の周期成分を反映しているためと考えられ る。すなわち、硬質な地盤ほど短周期で応答加速度が大きくなること、逆に軟質な地盤ほど材料非線形 化によって短周期で応答加速度が小さくなることがあることを反映していると考えられる。

\section{4. $2.3 P$ P V と被害率の関係}

PGV と宅地被害率の関係では、盛土・切盛境界・切土区分ともにばらつきが大きいが、近似曲線では 比例関係が認められる（図22）。このことから、PGVは宅地地盤の被害に対しては影響があると思われ る。また、PGVと木造建物被害率の関係では、全壊および半壊以上の木造建物被害率は盛土、切盛境界、 切土ともにばらつきが大きいが、PGVに比例して増加する傾向が認められる（図24）。これより、PGV は木造建物被害と相関性があると思われる。

\section{2.4 計測震度、PG A、P G と 被害の関係}

計測震度、PGA、PGVと各被害の相関関係をまとめて表4に示す。同表より、計測震度は木造建物被害 と相関性は高いが、宅地地盤被害との相関性は切盛境界を除いて低い。PGAは宅地地盤の切盛境界の被 害との相関性は高いが、盛土と切土の被害との差はない。また、PGAと木造建物被害については、半壊 以上の被害との相関性は比較的高いが、全壊被害との差はない。PGVは宅地地盤および木造建物被害と もに回帰式の相関性は認められるが、決定係数 $\mathrm{R}^{2} か ゙ 0.8$ 以を示し相関性はあまり高くはない結果が得ら れた（ただし、宅地地盤被害のうち切盛境界と切土との相関性は高い）。これより、木造建物被害の推 定には計測震度が優れ、宅地地盤被害と木造建物被害を同時に推定する場合はPGVが適するものと考え られる。 
表 4 計測震度、PGA、PGV と各被害の相関関係

\begin{tabular}{|c|c|c|c|c|c|c|c|c|}
\hline \multirow{3}{*}{ 地盤区分 } & \multirow{3}{*}{\multicolumn{2}{|c|}{ 被害 }} & \multicolumn{6}{|c|}{ 地震動特性 } \\
\hline & & & \multicolumn{2}{|c|}{$\begin{array}{l}\text { 計測震度 } \\
(5.2 \sim 6.0)\end{array}$} & \multicolumn{2}{|c|}{$\begin{array}{c}\text { PGA } \\
(300 \sim 700 \mathrm{Gal})\end{array}$} & \multicolumn{2}{|c|}{$\begin{array}{c}\text { PGV } \\
(30 \sim 60 \mathrm{~cm} / \mathrm{s})\end{array}$} \\
\hline & & & 相関性 & $\begin{array}{c}\text { 回帰式の } \\
\text { 決定係数 } \mathrm{R}^{2}\end{array}$ & 相関性 & $\begin{array}{l}\text { 回帰式の } \\
\text { 決定係数 } \mathrm{R}^{2}\end{array}$ & 相関性 & $\begin{array}{l}\text { 回帰式の } \\
\text { 決定係数 } \mathrm{R}^{2}\end{array}$ \\
\hline \multirow{3}{*}{ 盛土 } & \multicolumn{2}{|c|}{ 宅地地盤 } & $\times$ & - & $x$ & - & $\triangle$ & 0.689 \\
\hline & \multirow{2}{*}{ 木造建物 } & 全壞 & 0 & 0.860 & $x$ & - & $\triangle$ & 0.602 \\
\hline & & 半壊以上 & 0 & 0.972 & 0 & 0.975 & $\triangle$ & 0.705 \\
\hline \multirow{3}{*}{ 切盛境界 } & \multicolumn{2}{|c|}{ 宅地地盤 } & 0 & 0.901 & 0 & 0.887 & 0 & 0.809 \\
\hline & \multirow{2}{*}{ 木造建物 } & 全壊 & $\bigcirc$ & 0.973 & $x$ & 0.275 & $\triangle$ & 0.711 \\
\hline & & 半壊以上 & 0 & 0.980 & $\triangle$ & 0.629 & $\triangle$ & 0.600 \\
\hline \multirow{3}{*}{ 切土 } & \multicolumn{2}{|c|}{ 宅地地盤 } & $\triangle$ & 0.744 & $x$ & - & 0 & 0.889 \\
\hline & \multirow{2}{*}{ 木造建物 } & 全壊 & 0 & 0.969 & $x$ & - & $\triangle$ & 0.636 \\
\hline & & 半壊以上 & 0 & 0.997 & 0 & 0.998 & $\triangle$ & 0.718 \\
\hline
\end{tabular}

※相関性は、回帰式の決定係数 $\mathrm{R}^{2} \geqq 0.8$ $\bigcirc 、 0.8>\mathrm{R}^{2} \geqq 0.5$ を、 $\mathrm{R}^{2}<0.5$ をとした。

\section{2.5 造成年代と被害率の関係}

造成年代と宅地被害率の関係では、図28に宅地の品質向上に関わる技術基準の施行または改定年を併 記して示す。同図より、宅地被害率は昭和40年付近以降にそれ以前よりも低下していることから、昭和 40年に仙台市が宅地造成等規制法に基づく宅地造成工事規制区域の指定を開始したことが影響している ものと推測される。なお、図28(3)(b)において、切土におけるH17〜 H21年の宅地被害率が大きい值を示 すが、これは被害宅地数は6箇所であったが母数の宅地数も78箇所と少なかったために特異な結果にな ったものと判断される（図29(3)(a)より、平成9年まで宅地数（=建物数）の母数は概ね数百箇所以上とな っている)。

また、造成年代と木造建物被害率の関係では、図29に建物に対する新耐震基準施行年（1981年）と、 宅地の品質向上に関わる技術基準の施行または改定年を併記して示す。同図(b)より、宅地の造成年代ご とに見た盛土上の木造建物被害率は、1981年の新耐震基準の施行前後で盛土上の木造建物被害（全壊） がそれほど変化していないので、盛土上の建物被害には新耐震基準施行の効果は特に認められない。ま た、全壊被害率は3.4.1(1)で示した宅地被害と同様に、昭和40年付近以降にそれ以前よりも低下している ことから、昭和40年に仙台市が宅地造成等規制法に基づく宅地造成工事規制区域の指定を開始した影響、 すなわち宅地地盤の品質向上が影響しているものと推測される。

\section{2.6 現地盤勾配と被害率の関係}

現地盤勾配と宅地地盤被害および木造建物被害 (全壊) の相関性は高いことが明らかとなった (図 31 、 33）。これは現地盤面の傾斜が急になるほど盛土の滑動に対する安定性は低くなることから、現地盤勾 配に比例して盛土の滑動に起因する変状被害が発生した可能性が考えられる。

\section{2.7 旧地形勾配と被害率の関係}

宅地被害では、盛土と地山（旧地形面）をすべり面とする滑動被害は殆ど確認されていないが、盛土 および切盛境界ともに旧地形勾配が概ね 10 度以上で被害率が大きくなる傾向（特に切盛境界で顕著）が 認められることから、地山との境界面をすべり面とする盛土の変形が発生した可能性が考えられる（図 34)。

また、旧地形勾配と木造建物被害（全壊）の関係では、盛土および切盛境界における全壊被害は旧地 
形勾配と明瞭な比例関係にはなく、旧地形勾配に関わらず概ね1 2\%を示す（図35）。これより、旧地形 勾配は木造建物の全壊被害への影響は小さいと判断される。

\section{2.8 盛土厚と被害率の関係}

盛土厚と宅地被害率の関係では、盛土厚6～8mで宅地被害率が最も高い值（約6\%）を示す（図36(b)）。 これは、切盛境界（盛土厚0～2m）の被害率（3.7\%）よりも高い。盛土の滑動被害が確認された地区に

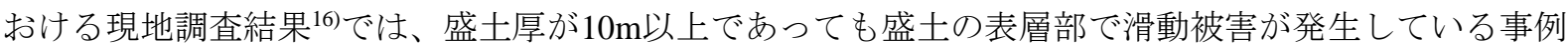
が報告されており、上記結果と整合する。

また、盛土厚と木造建物被害（全壊）の関係では、全壊被害率は概ね 1 1 2\%の範囲内にあり、盛土厚4 ～6mの場合で木造全壊建物被害率が最も高い值（2.5\%）を示す（図37(b)）。これは、切盛境界（盛土厚 0～2m）の被害率（1.5\%）よりも高い。これより、盛土厚と木造建物被害（全壊）の関係は、宅地被害 と類似した傾向が得られたことから、盛土表層部の変状の影響により被害が大きくなったことが推察さ れる。

\section{3 建物特性別被害}

\section{3.1 建築年代と木造建物被害率の関係}

建築年代と木造建物被害率の関係では、切土の被害割合を基準にすると、盛土では昭和 55 年以前で 4.8 倍、昭和56年以降で8.0倍、切盛境界では昭和55年以前で4.0倍、昭和56年以降で5.0倍をそれぞれ示す（表 3）。これより、盛土および切盛境界における地盤の変状の影響が大きいことが推測される。

\section{3.2 基礎の被害率}

基礎の被害率75\%以上の被害箇所の被害率では、切土の被害率と盛土および切盛境界の被害率に大差 がないことから、地盤変位（盛土の滑動や不同沈下）に起因する基礎被害は少なかった可能性がある（図 40)。

\section{5 結論}

仙台市丘陵地造成宅地を盛土・切盛境界・切土に区分し、2011年東北地方太平洋沖地震における宅地 被害と木造建物被害の分析をおこなった。その結果、以下のことが明らかとなった。

1）造成宅地全体の被害、地震動特性（計測震度、PGA、PGV）、地盤特性（造成年代、現地盤勾配）、 建物特性（建築年代、基礎の被害率75\%以上の被害）について、それぞれ宅地被害率および木造建物 被害率を分析し切土の被害率と比較した結果は、表5にまとめて示すとおりである。

2）宅地被害では、盛土の被害率は切土の概ね3 5 倍、切盛境界は概ね2 2 4倍を示す。同様に、木造建物 全壊被害では、盛土は2～10倍、切盛境界は2７倍を示し、半壊以上では盛土・切盛境界ともに概社 2倍を示す。これより、盛土および切盛境界における地盤の影響が大きいことが推測される。なお、 一部損壊被害は、盛土・切盛境界・切土区分に関係なく、被害率は17\%程度を示す。

3）造成年代では、宅地被害および木造建物被害（全壊）ともに平成元年付近以前の造成地で被害が発生 し、昭和 40 年付近を境界として被害率に差が認められた。

4）現地盤勾配では、勾配に概衫比例して被害率が増加し、6度未満、6〜10度、10度以上で宅地被害率お よび木造建物被害率（全壊）に差が認められた。

5）旧地形勾配と宅地被害の関係では、盛土・切盛境界ともに勾配に比例して被害率が大きくなる傾向が 認められ、特に切盛境界の方が明瞭である。また、木造建物被害（全壊）では、盛土および切盛境界 ともに旧地形勾配との関係は明瞭ではなく、どちらも被害率は概ね1〜2\%でほぼ一定である。

6）盛土厚と宅地被害の関係では、盛土厚が $8 \mathrm{~m}$ 付近までは盛土厚に比例して被害率が増加するが、盛土 厚が $8 \mathrm{~m}$ 付近よりも厚くなると宅地被害率は同じかやや低くなる傾向が認められる。また、木造建物被

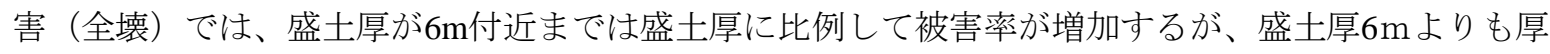
くなると被害率は同じかやや低くなる傾向が認められる。 
7）建築年と木造建物被害率の関係では、新耐震基準が施行された昭和56年以降の被害率と比べると、昭 和55年以前の建物被害率は2〜4倍高い。

8）全壊被害のうち基礎の被害率 $75 \%$ 以上の被害箇所が占める割合では、切土と盛土および切盛境界の被 害率に大差がない。これより、地盤変位に起因寸る基礎の被害は少なかった可能性がある。

9) 木造建物被害の推定には計測震度が優れ、宅地地盤被害と木造建物被害を同時に推定する場合はPGV が適する。

表 5 被害要因における宅地被害率および木造建物被害率一覧

\begin{tabular}{|c|c|c|c|c|c|c|c|c|}
\hline \multirow{2}{*}{ 分類 } & \multirow{2}{*}{\multicolumn{2}{|c|}{ 比較項目 }} & \multirow{2}{*}{ 対象 } & \multicolumn{3}{|c|}{ 被害率 (\%) } & \multicolumn{2}{|c|}{$\begin{array}{c}\text { 切土の被害率を基準 } \\
\text { とした場合の倍率 }\end{array}$} \\
\hline & & & & 盛土 & 切盛境界 & 切土 & 盛土 & 切盛境界 \\
\hline \multirow{4}{*}{ 全体 } & & & 宅地被害 & 4.8 & 3.2 & 1.1 & 4.4 & 2.9 \\
\hline & & & 木造建物被害（全壊） & 1.9 & 1.3 & 0.3 & 6.3 & 4.3 \\
\hline & & & 木造建物被害（半壊以上） & 16.6 & 12.6 & 7.3 & 2.3 & 1.7 \\
\hline & & & 木造建物被害（一部損壊） & 17.8 & 16.5 & 17.1 & 1.0 & 1.0 \\
\hline \multirow{9}{*}{$\begin{array}{c}\text { 地震動 } \\
\text { 特性 }\end{array}$} & \multirow{3}{*}{\multicolumn{2}{|c|}{ 計測震度【5.8〜6.0】 }} & 宅地被害 & 4.3 & 4.1 & 1.2 & 3.6 & 3.4 \\
\hline & & & 木造建物被害（全壊） & 2.5 & 2.0 & 0.4 & 6.3 & 5.0 \\
\hline & & & 木造建物被害（半壊以上） & 22.0 & 16.7 & 10.7 & 2.1 & 1.6 \\
\hline & \multirow{3}{*}{\multicolumn{2}{|c|}{ PGA【600 700gal】 }} & 宅地被害 & 4.1 & 3.8 & 0.9 & 4.6 & 4.2 \\
\hline & & & 木造建物被害（全壊） & 1.9 & 1.4 & 0.2 & 9.5 & 7.0 \\
\hline & & & 木造建物被害（半壊以上） & 18.9 & 13.8 & 7.7 & 2.5 & 1.8 \\
\hline & \multirow{3}{*}{\multicolumn{2}{|c|}{ 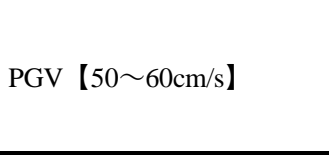 }} & 宅地被害 & 6.4 & 4.6 & 1.7 & 3.8 & 2.7 \\
\hline & & & 木造建物被害（全壊） & 3.0 & 1.8 & 0.5 & 6.0 & 3.6 \\
\hline & & & 木造建物被害（半壊以上） & 21.7 & 16.1 & 10.3 & 2.1 & 1.6 \\
\hline \multirow{10}{*}{$\begin{array}{l}\text { 地盤 } \\
\text { 特性 }\end{array}$} & \multirow{4}{*}{$\begin{array}{l}\text { 造成 } \\
\text { 年代 }\end{array}$} & \multirow{2}{*}{ 【昭和40年以前】 } & 宅地被害 & 10 以上 & 約6 & 約 2 & 約5 & 約3 \\
\hline & & & 木造建物被害（全壊） & $3 \sim 8$ & 約 2 & 約1 & $3 \sim 8$ & 約2 \\
\hline & & \multirow{2}{*}{ 【昭和40年以降】 } & 宅地被害 & 5以下 & 4以下 & 1以下 & 約5 & 約4 \\
\hline & & & 木造建物被害（全壊） & 1以下 & 1以下 & 0.5 以下 & 約 2 & 約2 \\
\hline & \multirow{6}{*}{$\begin{array}{l}\text { 現 } \\
\text { 地 } \\
\text { 盤 } \\
\text { 配 }\end{array}$} & \multirow{2}{*}{ 【0～6度】 } & 宅地被害 & 3.2 & 1.7 & 0.6 & 5.3 & 2.8 \\
\hline & & & 木造建物被害（全壊） & 1.5 & 0.9 & 0.2 & 7.5 & 4.5 \\
\hline & & \multirow{2}{*}{ 【6～10度】 } & 宅地被害 & 9.1 & 4.8 & 2.1 & 4.3 & 2.3 \\
\hline & & & 木造建物被害（全壊） & 3.2 & 1.6 & 0.4 & 8.0 & 4.0 \\
\hline & & \multirow{2}{*}{ 【10度以上】 } & 宅地被害 & 14.5 & 8.7 & 4.8 & 3.0 & 1.8 \\
\hline & & & 木造建物被害（全壊） & 4.8 & 2.5 & 1.0 & 4.8 & 2.5 \\
\hline \multirow{3}{*}{$\begin{array}{l}\text { 建物 } \\
\text { 特性 }\end{array}$} & 建築 & 【昭和55年以前】 & 木造建物被害（全壊） & 3.8 & 3.2 & 0.8 & 4.8 & 4.0 \\
\hline & 年代 & 【昭和56年以降】 & 木造建物被害（全壊） & 1.6 & 1.0 & 0.2 & 8.0 & 5.0 \\
\hline & \multicolumn{2}{|c|}{ 基䃈の被害率75\%以上 } & 木造建物被害（全壊） & 29.4 & 23.9 & 25.2 & 1.2 & 0.9 \\
\hline
\end{tabular}

\section{謝 辞}

本論の作成に当たっては、仙台市から宅地および木造建物被害調査データ、切盛図データ、造成年代 図データのご提供を頂いた。ここに記して御礼申し上げます。 


\section{参考文献}

1）地盤工学会：2.4宅地盛土、既設盛土の耐震性に関寸る検討委員会報告書、2009年.

2）（株）復建技術コンサルタント：造成宅地地盤図、2008年.

3）仙台市：仙台市宅地造成履歴等情報マップ（切土・盛土図）、2013年.

<http://www.city.sendai.jp/kurashi/bosai/shiryo/rirekimap.html, 2014年9月13日閲覽〉

（株）復建技術コンサルタントが仙台市の委託を受けて作成した.

4）被災宅地危険度判定連絡協議会 : 被災宅地の調査・危険度判定マニュアルおよび擁壁・のり面等被害 状況調査・危険度判定票作成の手引き、2009年.

<http://www.hisaitakuti.jp/download.html, 2014年9月13日閲覧〉

5）内閣府：平成23年東北地方太平洋沖地震に係る住家被害認定の調査方法、2011年3月31日策定、2011 年4月12日改正. 〈http://www.bousai.go.jp/taisaku/pdf/h23jishin.pdf, 2014年9月13日閲覧〉

6）国土地理院：技術資料D・1-№558「人工改変地形データ抽出のための手順書 概要版」、2010年、 または、国土交通省 : 大規模盛土造成地の変動予測調查ガイドラインの解説、2012年、pp19-20.

<http://www.mlit.go.jp/common/000209181.pdf, 2014年5月6日閲覧〉

7）仙台市：仙台市宅地造成履歴等情報マップ（造成年代図）、2013年. <http://www.city.sendai.jp/kurashi/bosai/shiryo/rirekimap.html, 2014年9月13日閲覧〉

8） Esri Japan Corporation：ArcGIS10.2 ヘルプライブラリー、傾斜角、ラスタツールの詳細、2012年. $<\mathrm{http} / / /$ resources.arcgis.com/ja/help/main/10.2/index.html\#//00qn0000001p000000, 2014年5月6日閲覧〉

9）東日本大震災に関する東北支部学術合同調査委員会: 平成23年（2011年）東北地方太平洋沖地震災害 調査報告書、1.4.6 宮城県および仙台市内での地震動、2013年、pp.53-57.

10）大野晋・柴山明寬：地盤増幅と地震動の空間相関を考慮した応答スペクトルの分布推定、第13回日 本地震工学シンポジウム論文集、2010年、pp.186-192.

11）大井昌弘・野畑有秀・水谷守・藤原広行 : 強震記録から見た地震動強さの指標間の関係、第11回日 本地震工学シンポジウム論文集、2002年、pp.633-638.

12）仙台市：平成14年度仙台市地震被害想定調査報告書、2002年.

13）建物総数は、国土地理院基盤地図情報における「建物」ポリゴンのうち「普通建物」に分類される ものとした. 国土交通省国土地理院、基盤地図情報ダウンロードデータ ファイル仕様書 第3.0版、 2010年.

14）佐藤真吾、栗谷将晴、南陽介 : 東北地方太平洋沖地震における谷埋め盛土造成宅地の被害と復旧課 題、第47回地盤工学研究発表会、2012年、pp. 1477-1478.

15） Esri Japan Corporation：ArcGIS Data Collection プレミアムシリーズ 2011住居レベル住所、2011年、 を使用して抽出した.

16）仙台市：仙台市宅地保全審議会技術専門委員会資料、第3回～第11回、2011年～2013年.

(受理：2014年11月2日）

（掲載決定：2015年3月12日） 


\title{
Damage classification of the reclaimed lands of residential area in the Sendai
} city after the 2011 off the Pacific coast of Tohoku Earthquake.

- Damage rates of wooden building and residential land on filled valley ,cutting hills and their boundary zone. -

\author{
SATO Shingo ${ }^{1)}$, KAZAMA Motoki ${ }^{2)}$, OHNO Susumu ${ }^{3)}$, \\ MORI Tomohiro ${ }^{4)}, \quad$ MINAMI Yosuke ${ }^{5)}$ and YAMAGUCHI Syuhei ${ }^{6)}$ \\ 1) Member, Chief, Fukken Gijyutsu Consultant, B. Eng. \\ 2) Member, Professor, Tohoku University, Dr. Eng. \\ 3) Member, Associate Professor, Tohoku University, Dr. Eng. \\ 4) Member, Assistant Professor, Tohoku University, Dr. Eng. \\ 5) Member, Chief Clerk Engineer, Fukken Gijyutsu Consultant, M. Eng. \\ 6) Member, Engineer, Fukken Gijyutsu Consultant, M. Eng.
}

\begin{abstract}
In the Tohoku earthquake, reclaimed lands as well as residential houses build on such a land were severely damaged. The present study investigates causes of those damages by classifying the properties of the input motion, ground conditions, and construction ages. As a result, compared with the damage rate of the houses located on a land constructed by cutting hills, those on filled valley and their boundary show much higher, more than double, damage rate.

Keywords:

Reclaimed lands, Wooden houses, Damage classification, cut and fill, the 2011 off the pacific coast of Tohoku Earthquake
\end{abstract}

